EFEITOS DA SECAGEM INTERMITENTE SQBRE A QUALIDADE DE SEMENTES DE MILHO

FRANCISCO AMARAL VILLELA

Engenheiro Agricola

Orientador: Prof. Dr. WALTER RODRIGUES DA SILVA

Tese apresentada à Escola Superior de Agricultura "Luiz de Queiroz", da Universidade de Så Paulo, para obtençao do título de Doutor em Agronomia. Area de Concentração: Fitotecnia.

$P$ I $R A C I C A B$

Estado de Sao Paulo - Brasil

Maio - 1991 
Ficha catalográfica preparada pela Seção de Livros da Divisão de Biblioteca e Documentação - PCAP/USP

Villela, Francisco Amaral

V735e Efeitos da secagem intermitente sobre a qualidade de sementes de milho. Piracicaba, 1991.

104p. ilus.

Tese - ESALQ

Bibliografia.

1. Milho - Secagem - Efeito 2. Milho - Semente Efeito da secagem 3. Milho - Semente - Qualidade I. Escola Superior de Agricultura Luiz de Queiroz, Piracicaba. 
EFEITOS DA SECAGEM INTERMITENTE SOBRE A QUALIDADE

\author{
DE SEMENTES DE MILHO
}

FRANCISCO AMARAL VILLELA

Aprovada em: 14.06 .1991

Comissao julgadora:

Prof. Dr. Walter Rodrigues da Silva ESALQ/USP

Prof. Dr. Júlio Marcos Filho ESALQ/USP

Prof. Dr. Silvio Moure Cicero ESALQ/USP

Prof. Dr. Joå Nakagawa ; FCA /UNESP

Prof. Dr. Joå Domingos Biagi FEA/UNICAMP

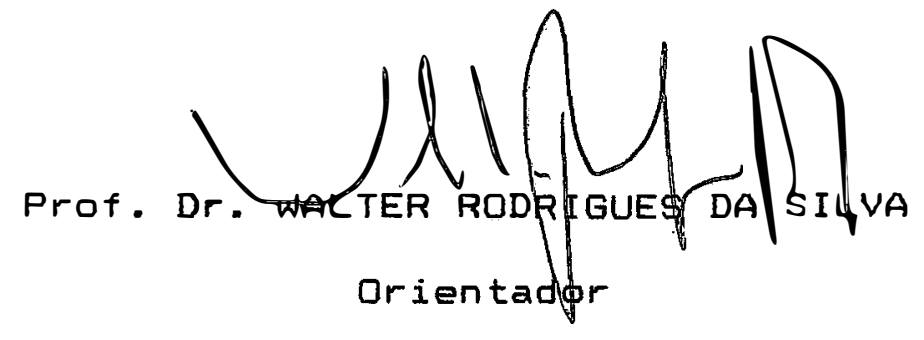


A meus pais (in memoriam) pelos principios de magnanimidade indulgencia e honradez.

A minha esposa, Llicia, pelo incentivo, apoio, dedicaçă e paciência.

A Deus, pelos

meus filhos

Luciano e Arthur.

A todo aquele que, por falta de oportunidade, permanece na ignorancia. 
AGRADECIMENTOS

Ao professor Walter Rodrigues da Silva, pela orientaçăo e assistência.

Ao Corpo Docente da ESALQ/USP, especialmente aos professores Júlio Marcos Filho, Silvio Moure Cicero, Paulo Yoshio Kageyama, Jairo Teixeira Mendes Abrahao e José Otávio Machado Menten, pela amizade e apoio.

Aos colegas de curso, em especial, aos amigos Maria Elizabete Doni, Luiz Doni Filho, Nilson Lemos de Menezes e José Garcia, pelo estimulo e colaboraçăo espontânea.

Aos servidores da ESALQ/USP, em especial à Engenheira Agrónoma Maria Heloisa Duarte Moraes e a Técnica Administrativa Ilze Helena Candida de Gaspari das Neves, pelo auxilio e sorriso oportuno.

Aos cunhados Marco e Beth, pela atençao e incentivo permanente.

A UFPel e à CAPES/PICD pelo suporte financeiro.

Aos colegas do Departamento de Fisica, IFM/UFPel, pela oportunidade de aperfeiçoamento concedida. Em particular, a professora Eny da Rosa Barboza pelo incentivo e apoio constantes.

A Sementes AGROCERES S/A, Unidade de Santa Cruz das Palmeiras, SP, pela cessăo das sementes e instalaçôes para a condução do trabalho.

A todos que de alguma forma contribuiram para. a realizaçăo do curso de doutorado. 
Página

LISTA DE FIGURAS ........................ vi

LISTA DE TABELAS ........................ vii

RESUMO............................... $x i i$

SUMMARY.............................

1. INTRODUÇÃO ............................ 1

2. Revisão de literatura .................... 4

3. MATERIAL E Metodos ......................... 7

3.1. Obtençå dos tratamentos .............. 28

3.2. Armazenamento das sementes ............. 30

3.3. Determinaçôs durante a secagem intermitente 31

3.4. Determinaçdes de laboratório .......... 32

3.5. Determinaçăo de campo ............... 36

3.6. Métodos estatisticos ................ 37

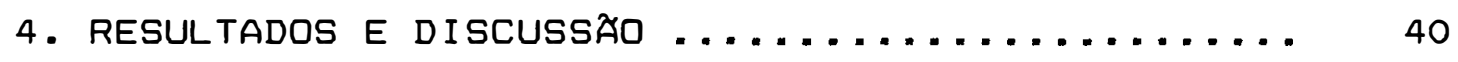

4.1. Caracterizaçă dos lotes ............... 40

4.2. Curvas de secagem .................... 42

4.3. Efeitos sobre a qualidade das sementes..... 53

4.3 .1 - Estudo $1 \ldots \ldots . . . \ldots . . . . . . . .53$

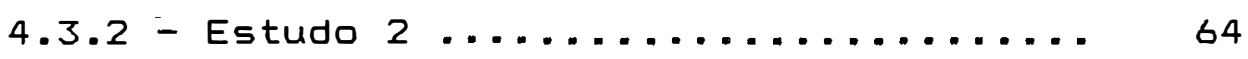

4.3 .3 - Estudo $3 \ldots \ldots \ldots . \ldots \ldots . \ldots . \ldots . \ldots 73$

4.4. Consideraçனes gerais ................. 83

5. CONCLUSOES ................................ . . . 89

REFERENCIAS BIBLIOGRÁFICAS ................ 90 


\section{LISTA DE FIGURAS}

Figura

Página

1. Curva caracteristica de secagem, representando a variaça do teor de água do produto em funça do tempo (adaptado de HALL,

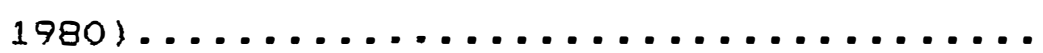

2. Curva de secagem representando o comportamento do teor de água das sementes de milho em funçăo do tempo. Secagem intermitente a temperatura do ar de $70 \circ \mathrm{C}$ (Estudo 1 )

3. Curva de secagem representando o comportamento do teor de água das sementes de milho em funçăo do tempo. Secagem intermitente a temperatura do ar de $800^{\circ}$ (Estudo 2)...

4. Curva de secagem representando o comportamento do teor de água das sementes de miIho em funçăo do tempo. Secagem intermitente a temperatura do ar de 900C(Estudo 3)...

5. Temperaturas máximas, medias e minimas ( ${ }^{\circ}$ ) e umidades relativas do ar medias (\%), por decêndios, registradas no periodo de 20/04/ 89 a $21 / 10 / 89$, em Piracicaba-SP.......... 


\section{LISTA DE TABELAS}

Tabela

Página

1. Esquema da análise da variancia dos dados de germinaçăo, envelhecimento rápido, frio sem

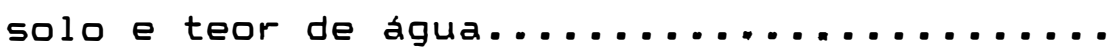

2. Esquema da análise da variância dos dados do teste de sanidade, exame de sementes infestadas e emergência em campo ..............

3. Esquema da análise da variância dos dados do teste de coloraça de tintura de iodo, exame de sementes com dano mecânico visivel e determinaçao do total de impurezas..........

4. Caracterizaçăo da qualidade inicial das sementes de milho, dos lotes A, B e C........

5. Dados referentes às determinaçôes realizadas durante a secagem intermitente das sementes de milho,empregando ar de secagem a temperatura de 700C (Estudo 1)................

6. Dados referentes as determinaçôes realizadas durante a secagem intermitente das sementes 
de milho,empregando ar de secagem a temperatura de $80^{\circ} \mathrm{C}$ (Estudo 2 ).................

7. Dados referentes às determinaçôes realizadas durante a secagem intermitente das sementes de milho,empregando ar de secagem a temperatura de $90^{\circ} \mathrm{C}$ (Estudo 3 )...............

8. Estudo 1. -Resultados da análise de variância (Teste F) dos dados referentes às determinaçôes para a avaliaçăo da qualidade de se-

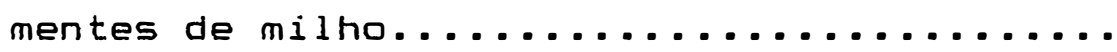

9. Estudo 1. - Comparação de médias dos dados do teste de coloraçăo de tintura de iodo (TCTI), exame de sementes com dano mecânico visivel (ESDMV) e determinaçåo do total de impurezas (DTI), para os efeitos de tratamentos de secagem $\ldots \ldots \ldots \ldots \ldots \ldots \ldots \ldots \ldots \ldots \ldots \ldots \ldots \ldots \ldots$

10. Estudo 1. - Comparação de médias dos dados de teor de água, germinaçao, envelhecimento rápido e frio sem solo, nas épocas $E_{2}, E_{72}$, $E_{3}$ e EA, para os efeitos de tratamentos de secagem......................... 
11. Estudo 1. - Comparação de medias dos dados de emergência em campo e de sementes infestadas, nas épocas $E_{2}$ e $E_{4}$, para os efeitos de tratamentos de secagem........

12. Estudo 1. - Comparaçăo de médias de incidência de Penicillium spp., Aspergillus spp., Fusarium moniliforme e Cephalosporium spp., nas épocas $E_{2}$ e $E_{4}$, para os efeitos de tratamentos de secagem..................

13. Estudo 2-Resultados da análise de variância (Teste F) dos dados referentes as determinaçôes para a avaliaçao da qualidade de sementes de milho ...................

14. Estudo 2. - Comparaçao de médias dos dados do teste de coloraça de tintura de iodo (TCTI), exame de sementes com dano mecânico visivel (ESDMV) e determinaçăo do total de impurezas (DTI), para os efeitos de tratamentos de secagem............

15. Estudo 2. Comparaçao de médias dos dados de teor de água,germinaçao, envelhecimento rápi- 
do e frio sem solo, nas épocas $E_{1}, E_{2}, E_{3}$ - E4. para os efeitos de tratamentos de secagem..

16. Estudo 2 - Comparaçăo de médias dos dados de emergência em campo e de sementes infestadas, nas épocas $E_{1}$ e $E_{4}$, para os efeitos de tratamentos de secagem ..............

17. Estudo 2. - Comparaçăo de médias de incidência de Penicillium spp., Aspergillus spp., Fusarium moniliforme e Cephalosporium spp., nas épocas $E_{1}$ e $E_{4}$, para os efeitos de tratamentos de secagem ..................

18. Estudo 3-Resultados da análise de variância ( Teste $F$ )dos dados referentes as determinaçôes para a avaliaçăo da qualidade de sementes de milho......................

19. Estudo 3. - Comparaçăo de médias do teste de coloraçăo de tintura de iodo (TCTI), exame de sementes com dano mecânico visivel (ESDMV)e determinaçăo do total de impurezas (DTI), para os efeitos de tratamentos de secagem ...................... 
20. Estudo 3. - Comparaçăo de médias dos dados de teor de água, germinaçă, envelhecimento rápido e frio sem solo, nas épocas $E_{2}, E_{2}$, $E_{: 3}$ e $E_{4}$, para os efeitos de tratameritos de secagem ........................

21. Estudo 3. - Comparaçăo de médias dos dados de emergência em campo e de sementes infestadas, nas épocas $E_{1}$ e $E_{4}$, para os efeitos de tratamentos de secagem ...............

22. Estuda 3. - Comparação de médias de incidência de Penicillium spp., Aspergillus spp., Fusarium moniliforme e Cephalosporium spp., nas épocas $E_{1}$ e $E_{4}$, para os efeitos de tratamentos de secagem ................... 


\title{
EFEITOS DA SECAGEM INTERMITENTE SOBRE A QUALIDADE DE SEMENTES DE MILHO
}

\author{
Autor: FRANCISCO AMARAL VILLELA
}

Orientador: PROF. DR. WALTER RODRIGUES DA SILVA

RESUMO

objetivando determinar as curvas de secagem e avaliar os efeitos de diferentes temperaturas do ar sobre a qualidade de sementes de milho, do hibrido duplo AG-162, durante a secagem, foi conduzido em Santa Cruz das Palmeiras e em Piracicaba, Sao Paulo, o presente trabalho dividido em três Estudos, denominados 1, 2 e 3. Cada Estudo envolveu três tratamentos de secagem: secagem natural, secagem artificial - natural e secagem artificial. Nas secagens artificial-natural e artificial dos três Estudos 
foram utilizadas, respectivamente, as temperaturas do ar de 70, 80 e 900 C, durante o processo denominado artificial (secagem intermitente).

Durante a secagem intermitente, foi monitorado o teor de água das sementes para a posterior determinaçao das curvas de secagem.

As sementes, após a secagem, foram armazenadas por seis meses e seu comportamento avaliado em quatro épocas bimestrais, através da determinaçăo do teor de água e dos testes de germinaçăo, envelhecimento rápido e frio sem solo. Para a identificaçao de sementes com danos mecânicos, na primeira época, foram conduzidos o teste de coloraça de tintura de iodo, o exame de sementes com dano mecânico visivel e a determinaçao do total de impurezas. Na primeira e quarta épocas, foram realizados o exame de sementes infestadas e os testes de sanidade e de emergência em campo. A análise e a interpretaçao dos resultados, considerando temperaturas do ar de secagem de 70,80 e 900 C e reduçoes do teor de água de 16,5 para $13,0 \%$, permitiram as seguintes conclusâes:

- A secagem intermitente nao causa efeitos prejudiciais à qualidade fisiológica de sementes de milho.

$$
\text { - A incidencia de Penicillium spp. em }
$$

sementes de milto pode ser reduzida com o emprego da secagem intermitente. 
- As curvas de secagem de sementes de milho, na secagem intermitente podem ser representadas por funçôes lineares.

- o aumento da velocidade de secagem e a reduçăo do tempo total de exposiçao das sementes ao ar aquecido podem ser obtidos pela elevaçao da temperatura do ar de secagem. 


\section{EFFECTS OF INTERMITTENT DRYING ON THE QUALITY OF MAIZE SEED}

Author: FRANCISCD AMARAL VILLELA Adviser: PROF. DR. WALTER RODRIGUES DA SILVA

\section{SUMMARY}

The objective of this work was the determination of the drying curve and the evaluation of the effects of different air temperatures on the quality of maize seeds, double hybrid $A G-162$, during the drying process. It was carried out in Santa Cruz das Palmeiras and Piracicaba, Sao Paulo, with three studies mamed 1, 2 and 3. Each study was made up of three drying treatments: natural drying, artificial-natural drying and artificial drying. In the artificial-natural drying and in the artificial drying on three studies, air temperatures at 70,80 and $900 \mathrm{C}$ were used, respectively, during the process named artificial (intermittent drying). During the intermittent drying, the moisture content of the seeds was monitored for further 
determina-tion of the drying curve.

After the drying process, the seeds were stored during six months and evaluations were carried out in four times every two months, by the determination of moisture content and germination, accelerated aging and cold without soil tests. In the first period, the indentification of mechanically damaged seeds was determined by the iodine coloration drying test, examination of visible mechanically damaged seeds and determination of total impurity. In the first and fourth periods seed infestation, seed health and field emergence tests were put into effect.

Considering the drying process temperature at 70,80 and $90^{\circ} \mathrm{C}$ and the moisture content reducing from $16,5 \%$ to $13,0 \%$, the conclusions were as follows:

- The intermittent drying did not cause prejudicial effects on the physiological quality of maize seeds.

- The Penicillium spp. incidence on maize seeds may be reduced by means of intermittent drying.

- The maize seeds drying curve for the intermittent drying process may be represented by linear functions.

- The increase of the drying speed and the reduction of total time of seeds exposition in hot air may be achieved by the elevation of the drying air temperature. 


\section{INTRODUCAO}

As sementes na maturidade fisiologica, apresentam os máximos poder germinztivo, vigor e peso de materia seca. Para milho, a nivel de campo, a formaça da camada negra, na regiăo de inserçă entre a semente e o sabugo, e o teor de água såo parãmetros que têm sido utilizados no diagndstico da maturidade das sementes.

Nesse ponto, as sementes de milho apresentam teores de água entre 28 e $35 \%$, nå compativeis com a tecnologia disponivel para a colheita mecânica com debulha. A partir dai, permanecem submetidas a fatores adversos de campo que săo potencialmente desfavoráveis à preservaçăo de sua qualidade.

Dessa forma, a colheita deve ser realizada tåo logo haja compatibilizaça entre o teor de água das sementes e o metodo a ser empregado o que', na maior parte dos casos, demanda a realizaça da secagem do material colitido.

Nas empresas produtoras de sementes de milho, uma das práticas utilizadas tem sido a colheita das espigas, quando as sementes atingem teores de água entre 25 
e 35\%. Após uma seleçao manual, as espigas são secadas em depósitos, com sistema de distribuiçao de ar quente forçado, necessitando, algumas vezes, 48 a 72 horas para que as sementes alcancem o teor de água de $13 \%$. Essa prática tem apresentado alguns inconvenientes, tais como, o consumo adicional de energia para a secagem do sabugo e o elevado tamanho das instalaçôes de secagem.

Uma possibilidade optativa é a de realizar a secagem em espigas até as sementes alcançarem teor de água de $16 \%$, proceder a debuliha e completar a secagem das sementes pelo método artificial, até $13 \%$.

Uma alternativa que vem sendo empregada, nas regioges onde, na época de colheita de sementes de milho, săo baixas a umidade relativa do ar e a precipitaçao pluvial, é a realizaça da colheita e debulha das sementes com teores de água entre 18 e $20 \%$ seguidas de secagem pelo método intermitente, até niveis seguros à conservaçăo do material durante o periodo de armazenamento.

0 método intermitente consiste em submeter as sementes à açăo do ar aquecido durante intervalos regulares de tempo (ciclos), intercalados por periodos sem aquecimento. o espaçamento entre os ciclos e a duraçăo de cada ciclo determinaråo variaçoes nos gradientes internos de temperatura e umidade nas sementes, podendo, em consequência, afetar a sua qualidade.

Entre outras vantagens, este método demanda 
menores consumo de energia e tempo total de secagem em relaçăo à secagem em espigas. .

Na secagem de sementes de milho em secador intermitente, as temperaturas do ar, nå excedem, em geral, $700 \mathrm{C}$.

Com a propósito de reduzir a tempo de secagem e, desta forma, aumentar a capacidade operacional dos equipamentos, existe a possibilidade de elevaçao da temperatura do ar de secagem, em secador intermitente.

Baseado nestas consideraçôes, o presente trabalho apresentou os seguintes objetivos:

- avaliar os efeitos de diferentes temperaturas do ar, na secagem intermitente, sobre a qualidade de sementes de milho;

- determinar as curvas de secagem de sementes de milho, para diferentes temperaturas do ar, durante a secagem intermitente. 


\section{REVISÃO DE LITERATURA}

A colheita é uma operaçao importante na produçåo de sementes, uma vez que o seu adequado planejamento e sua perfeita execução contribuem para reduzir perdas qualitativas e quantitativas. As sementes, por ocasiao da colheita, nem sempre se encontram com teores de água compativeis com sua adequada conservaçăo, levando-se a considerar a secagem como uma operaçao que merece atençăo especial dentro do processo de produçăo.

Na maturidade fisiológica, o teor de água das sementes é elevado, o que inviabiliza a colheita mecânica com debulha. Entretanto, tåo logo seja possivel, a colheita deve ser realizada.

MATTHES et alii (1969) afirmaram que a colheita precoce de sementes reduz os danos que ocorrem no campo devido à incidência de doenças, ao ataque de pragas e as condiçôes climáticas adversas. Recomendaram, ainda, que para regibes de clima tropical e subtropical, as sementes de milho sejam colnidas com teores de água entre 25 e 35\% para serem, em seguida, secadas por meio artificial até um 
nivel adequado para preservaçăo de sua qualidade fisiológica durante o armazenamento. .

A permanência das sementes com elevado teor de água, durante o periodo compreendido entre a colheita e a secagem, contribui para acelerar o processo de deterioraçăo devido à elevada atividade metabólica que, além de consumir as substâncias de reserva, libera energia e água favorecendo o desenvolvimento de microrganismos e insetos.

o teor de água ideal para o armazenamento depende da espécie, das condiçaes ambientais, do periodo e do tipo de embalagem empregado (HARRINGTON, 1973 e BASKIN, 1975).

Em regides de clima tropical e subtropical, - teor de água das sementes após a colheita precisa ser rapidamente reduzido a $12 \%$ ou menos, para sementes de cereais como milho e trigo, e a $11 \%$ ou menos, para a maioria das outras espécies (DELOUCHE et alii, 1973; DELOUCHE \& POTTS, 1974).

As sementes, por serem higroscópicas, possuem a propriedade de realizar intercâmbio de água, sob a forma de vapor com a ar circundante, por sorçao ou dessorçao, até alcançarem o ponto de equilibrio higroscopico ou teor de água de equilibrio (NELLIST \& HUGUES, 1973; BROOKER et alii, 1974; KEEY, 1975).

0 teor de água de equilibrio depende, dentre outros fatores, da composiçao quimica das sementes, umidade 
relativa do ar, temperatura, histerese, tamanho das sementes e condiçăo fisica das sementes.d As sementes amiláceas, como milho e trigo, apresentam ponto de equilibrio higroscópico maior em relaçao as sementes oleaginosas, como algodao e amendoim, para uma mesma condiçao climática, visto que os carboidratos mostram maior afinidade higroscópica do que os lipidios (GUILBOT et alii, 1973; POPINIGIS, 1985; COPELAND \& MACDONALD, 1985; CARVALHO \& NAKAGAWA, 1988 ).

Em funçăo da naturęza das ligaçôes fisico-quimicas existentes entre os componentes da semente e as moléculas de água, a água na semente apresenta-se sob quatro formas diferentes (ROCKLAND, 1969; LASSERAN, 1978; COPELAND \& MACDONALD, 1985), a saber: a) água em monocamada, constituida por uma camada monomolecular em torno das macromoléculas da matriz, ligada por meio de ligaçoes iônicas aos grupos carboxila e amino; b) água em multicamada, formada por uma camada polimolecular, que se fixa sobre a camada monomolecular anteriormente descrita, ligada através de pontes de hidrogênio, aos grupos hidroxila e amida; c) água osmótica, constituida de água liquida sob tensao osmótica, que retém diferentes substancias dissolvidas nas células; d) água livre, retida mecanicamente pelas paredes celulares, ocupando os espaços intercelulares.

A água livre necessita para sua evaporaçao, 
energia ao nivel de calor latente de vaporizaçao sendo, dessa forma, facilmente removida por ocasiao da secagem. As formas de água, osmótica, em multicamada e em monocamada, por sua vez, apresentam suas moléculas ligadas ás estruturas sólidas das sementes através de ligaçôes fisico-quimicas, cujos niveis energéticos crescem da água osmótica para a em monocamada. Estas formas de água necessitam maior nivel de energia para sua remoçao sendo, portanto, de retirada mais dificil durante a secagem (LASSERAN, 1978; -PARK, 1988).

A água na fase liquida é constituida de moléculas que estao em continuo movimento, cuja velocidade e distância média percorrida variam em funça da temperatura. - formecimento de calor estimula a movimentaçao molecular, pela reduçao das forças de atraçao, promovendo a formaçă de vapor dágua (COATES, 1960; CAVARIANI \& BAUDET, 1982).

Pressao de vapor é a expressao da força exercida pelas mọléculas do vapor por unidade de área quando, na interface entre um liquido e o seu vapor, existe equilibrio entre a taxa de vaporizaço do liquido e a taxa de condensaçắ do vapor (LEE \& SEARS, 1969).

a vapor dágua, presente na semente tende a ocupar todos os espaços intercelulares disponiveis, gerando pressies em todas as direçôes, inclusive na interface entre a semente e o ar que, por sua vez,. é denominada pressáo parcial de vapor dágua na superficie da semente(LASSERAN, 
1978). A água presente no ar, sob a forma de vapor, exerce uma presså parcial, variável em funçă da sua concentraçă e da temperatura, denominada pressao parcial de vapor dágua do ar (LEE \& SEARS, 1969).

0 processo de secagem visa a retirada parcial da água da semente, através da transferência simultanea de calor do ar para a semente e de massa, por meio do fluxo de vapor dágua, da semente para o ar (FOUST et alii, 1982; PARK, 1988).

A secagem de sementes, mediante conveçå forçada de ar promove, essencialmente, dois processos simultâneos: a) transferência de água da superficie da semente para o ar circundante, que ocorre quando a pressao parcial de vapor na superficie da semente é maior do que a no ar circundante; b) movimento de água do interior para a superficie da semente, em virtude do gradiente de potencial hidrico, durante o processo, entre as duas regibes.

Diversos mecanismos têm sido propostos para descrever o movimento da água do interior para a superficie de una estrutura sólida (BROOKER et alii, 1974; KEEY, 1978; SODHA et alii, 1987, PARK, 1988): a) difusao liquida - movimento de água na fase liquida devido ao gradiente de sua concentraça; b) difusao de vapor - mavimento de vapor dágua motivado pelo gradiente de temperatura; cl fluxo hidrodinâmico - escoamento de liquido e vapor em decorrência de diferenças na pressao total, causadas por gradiente de 
presså externa, contraçăo, concentraçao, temperatura e forças capilares; d) fluxo capilar movimento de água na fase liquida em virtude das forças capilares, independentemente da concentraçåo de água; e) difusåo superficial - movimento de água na fase liquida ocasionado pela sua difusao numa superficie porosa. Este último mecanismo nao é levado em consideraça, na maioria das teorias de secagem, pelo fato de apresentar efeito praticamente desprezivel.

$$
\text { Em sementes, LASSERAN (1978) sugeriu que o }
$$

fluxo de água do interior para a superficie, durante a secagem, é ocasionado por um derramamento hidrodinâmico sob a açao da pressao total interna e/ou por um processo de difusão resultante de gradientes internos de temperatura e teor de água ou de um gradiente de pressáo osmotica.

o consumo de calor provocado pela evaporaçao da água é acompanhado por um resfriamento da massa de ar. A adsorçao do vapor dágua pelo ar permite que, embora ocorra - abaixamento da temperatura, o balanço energético global das trocas seja nulo porque o ar recupera, sob a forma de vapor, o que perdeu sob a forma de calor sensivel. o resfriamento do ar no curso da secagem é apenas parcial, visto que é necessário que o ar permaneça suficientemente aquecido para adsorver a maior quantidade possivel de água, cuja capacidade de adsorçăo aumenta em funçăo da temperatura (KNEULE, 1966; LASSERAN, 1978).

o processo de secagem de um produto, sob 
condiçôes constantes de temperatura, umidade relativa do ar e velocidade do ar, pode ser dividido em um periodo de velocidade constante e outro de velocidade decrescente, conforme indica a Figura l (HALL, 1980):

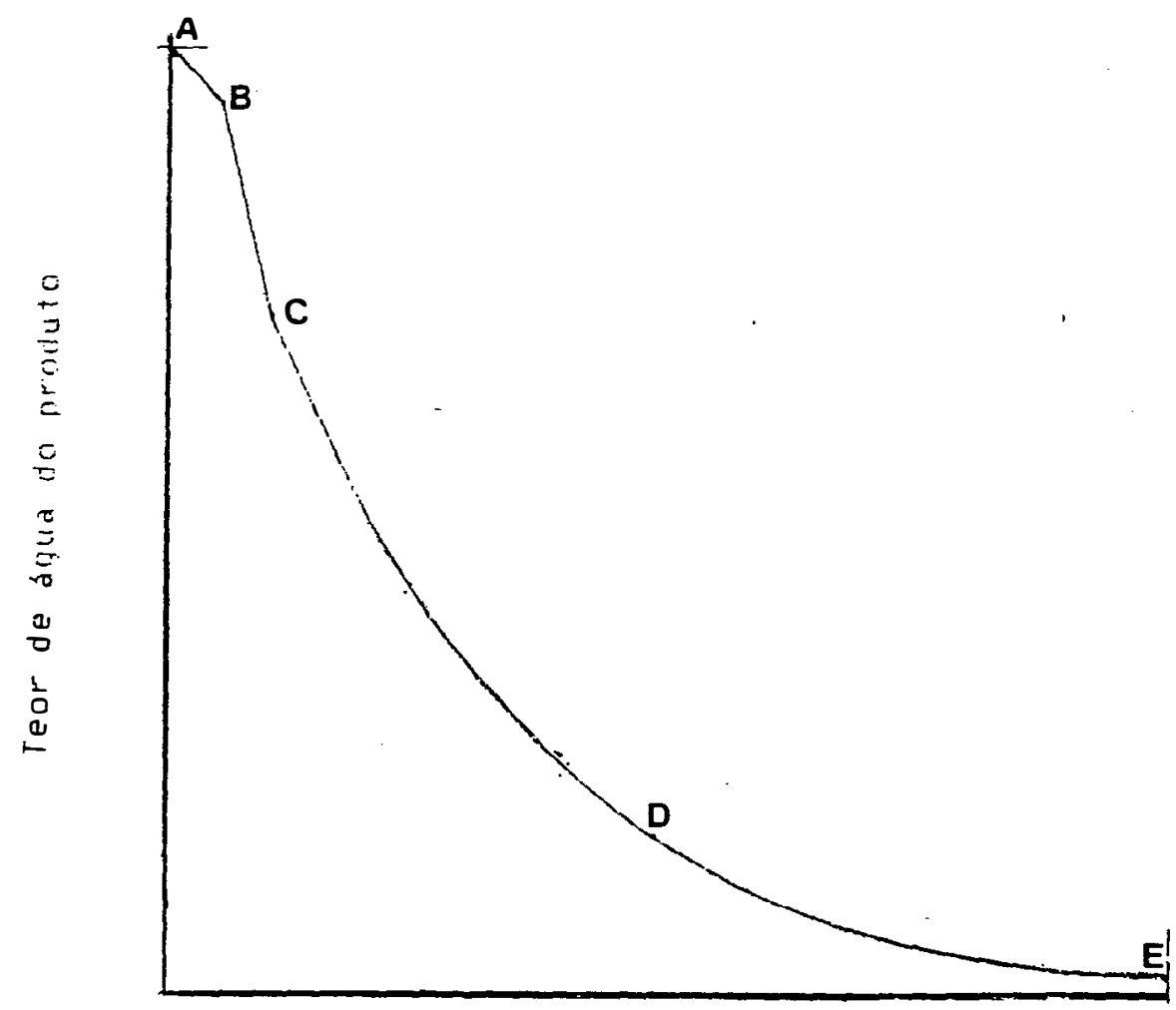

Tempo

Legenda:

$A B$ - periodo de induçao

$B C$ - periodo de velocidade constante

CD - estádio de superficie insaturada

$D E$ - estádio de controle interno de umidade

Figura 1 - Curva caracteristica de secagem, representando a variaçao do teor de água do produto em funçao do tempo(adaptado de HALL,1980). 
o periodo de secagem, representado pelo segmento $A B$ da curva caracteristica de secagem, indicado na Figura 1, é o periodo de induçao. e ocorre quando o produto está mais frio do que o ar de secagem, de tal forma que sua temperatura aumenta até atingir um patamar constante. Durante o periodo de velocidade constante, representado pelo segmento $\mathrm{BC}$, a temperatura do produto se mantém igual à de saturaçao do ar de secagem. As transferências de calor e massa se compensam e a velocidade de secagem é constante, alcançando seu valor máximo. O mecanismo interno de fluxo de água nao afeta a velocidade de secagem porque a taxa de deslocamento interno da água para a superficie do produto é igual ou maior do que a máxima taxa de remoçå de vapor dágua pelo ar, sendo evaporada apenas a água livre (HALL, 1980 ; FOUST et alii, 1982; SODHA et alii, 1987).

As sementes, em geral, apresentam o periodo de secagem com velocidade constante muito curto, ou inexistente, porque, nas condiçöes operacionais de secagem, as resistências as transferências de água encontram-se essencialmente no seu interior, tornando a taxa de evaporaçao superficial acentuadamente superior à taxa de reposição de água do interior para a superficie (KREYGER, 1973; BROOKER et alii, 1974; LASSERAN, 1978).

Durante o periodo de velocidade constante, conforme SODHA et alii (1987), a velocidade de secagem depende da diferença entre as pressaes parciais de vapor 
dágua na superficie do produto e no ar, da área da interface produto/ar, dos coeficientes de transferência de calor e massa e da diferença de temperatura entre o ar e superficie do produto. Os coeficientes de transferencia de calor e massa så afetados pela velocidade do ar, tipo de escoamento do ar (laminar ou turbulento), geometria da interface ar-produto e caracteristicas da camada de ar em contato com o produto (fluxo paralelo ou perpendicular a superficie de secagem).

A velocidade de secagem neste periodo pode ser expressa pela seguinte equaçăo (HENDERSON \& PERRY, 1955; BROOKER et alii, 1974; SODHA et alii, 1987):

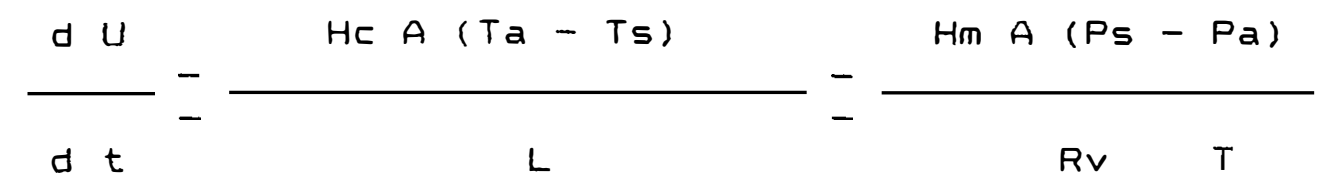

onde:

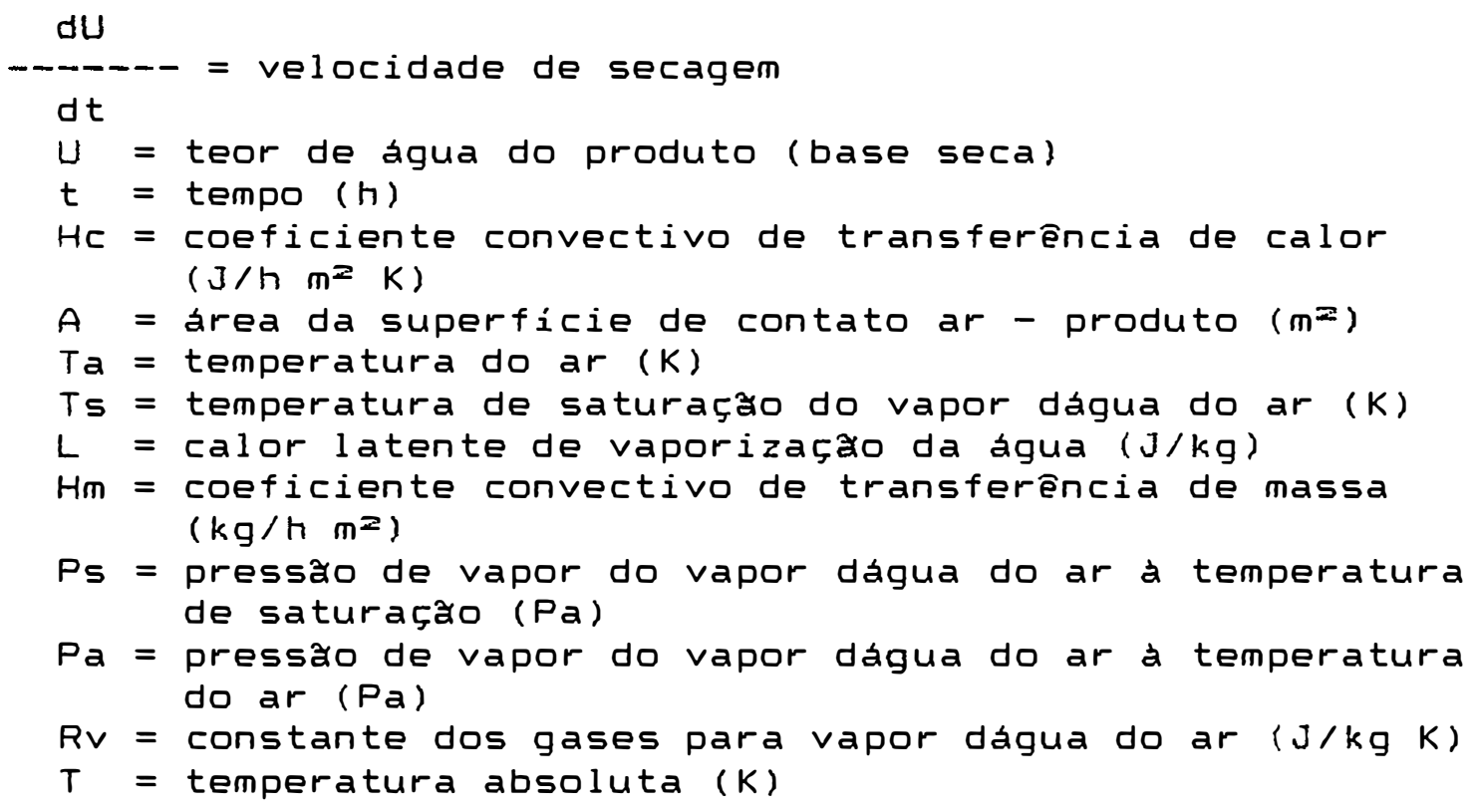


No periodo de velocidade decrescente. de secagem, representado na Figura l pelo segmento CE, a taxa de transporte interno de água é menor do que a taxa de evaporaçă desta forma a transferência de calor nåo é compensada pela transferência de massa e, em consequência, a temperatura da semente aumenta, teridendo a temperatura do ar de secagem.

o periodo de velocidade decrescente pode ser dividido em dois estádios (FORTES, 1978; ALVARENGA, 1979; HALL, 1980; FOUST et alii, 1982):

a) estádio de superficie insaturada, representado pelo segmento CD"na Figura 1, quando nåo há continuidade de evaporaçă em toda a superficie do produto, decrescendo a taxa total de evaporaçă superficial. 0 transporte de água no interior do produto ocorre por difusao liquida e difusåo de vapor.

b) estádio de controle interno de umidade, representado pelo segmento DE na figura 1, quando a regiao de vaporizaçăo situa-se no interior do produto e a velocidade de secagem é determinada pelo movimento interno de água. Neste estádio, a velocidade de secagem decresce rapidamente e o transporte de água ocorre, principalmente, por evaporaçôes e condensaçôes sucessivas.

o processo de secagem, durante o periodo de velocidade decrescente, fundamenta-se em duas teorias básicas (KEEY, 1975; KEEY, 1978; FORTES, 1978; FOUST et alii, 
1982; PARK, 1988):

a) a teoria difusional considera a difusão de água na fase liquida como o principal mecanismo de secagem de sementes. A velocidade de transporte da água para o movimento unidimensional, pode ser expressa pela segunda Lei de Fick:

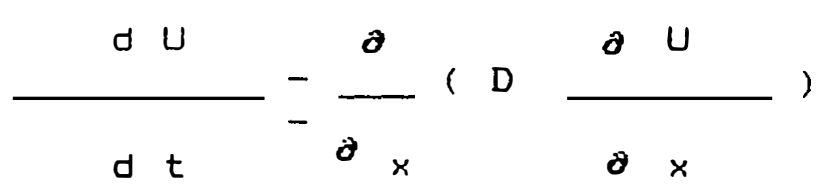

onde:

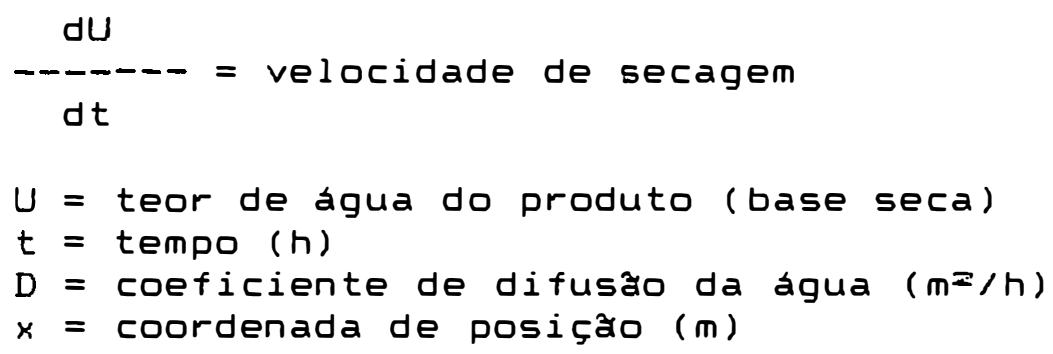

b) a teoria capilar afirma que o movimento de água num produto é ocasionado por forças capilares, resultantes dos efeitos das diferenças entre a pressao hidrostática e a tensao superficial. O fluxo capilar pode ser expresso pela seguinte equaçăo:

$$
\overrightarrow{\mathrm{J}}=\mathrm{K}_{\mathrm{n}} \neq
$$

onde:

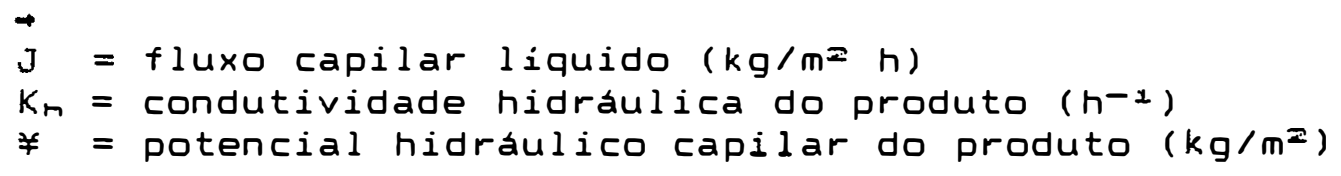


A teoria capilar embora nao se aplique as sementes por nåo serem materiais tipicamente capilares, fornece subsidios para fundamentar as equaçoes dos processos de transferência de calor e massa (KEEY, 1978; PARK, 1988).

A remoçao de água das sementes, durante a secagem, pode causar alteraços quimicas, fisicas e biologicas, tornando criticas as condiçâes de realizaçăo da secagem, as quais devem ser escolihidas tendo em vista, primordialmente, os efeitos que podem ter sobre a qualidade da semente.

Os métodos de secagem de sementes podem ser divididos,basicamente,em dois conjuntos:a)secagem naturalobtida pela exposiça da semente ao sol ou pela sua permanência em ambiente atmosférico relativamente seco, pode ser realizada em terreiros, tabuleiros ou encerados, dependendo da quantidade de sementes e da disponibilidade de locais para a secagem; b) secagem artificial - obtida ao submeter-se a semente, num secador, a açăo de um fluxo de ar, aquecido ou nåo, é um processo geralmente dispendioso em energia, que permite reduzir o teor de água das sementes, num periodo de tempo relativamente curto, dependendo do método de secagem e das condiçâs climáticas da regiå.

Os métodos de secagem artificial, quanto ao fluxo das sementes no secador, podem ser classificados em 
duas categorias (KREYGER, 1973; BROOKER et alii, 1974; SILVEIRA, 1976; TOLEDO \& MARCOS FILHO, 1977; LASSERAN, 1979; CABELLO, 1982; SILVA et alii, 1983): a) secagem esta-. cionária. - consiste basicamente em se forçar um fluxo de ar através da massa de sementes que permanece em repouso; b) secagem de fluxo continuo. - consiste em submeter as sementes a uma corrente de ar, enquanto elas fluem continuamente através do secador.

A secagem estacionária se processa da base para o topo da camada de sementes, em secador de fundo falso perfurado e do centro para a periferia, em secador de tubo central perfurado; ocorre por camadas, em virtude da formaçao da zona de secagem, correspondente à regiao onde efetiva-se o intercambio de agua da semente para o ar. Anteriormente a zona de secagem tem-se sementes secas e alta temperatura e, posteriormente, sementes úmidas e baixa temperatura (WELCH, 1967; PESKE \& BAUDET, 1980; CAVARIANI \& BAUDET, 1982).

Algumas precauçöes especiais devem ser tomadas na secagem estacionária, a fim de evitar a supersecagem na camada de sementes mais próxima a entrada de ar aquecido e permitir a secagem da camada mais distante, o mais rápido possivel, para que nå ocorra deterioraçăo das sementes. Så recomendados, para sementes com teores de água entre 16 e $18 \%$, fluxos de ar entre 8 e $10 \mathrm{~m} / \mathrm{min} / \mathrm{t}$, espessura da camada de sementes nåo superior a 1,5 m, para 
sementes de tamanho similar ao da soja, umidade relativa do ar de secagem nå inferior a 40\% e temperatura máxima do ar de secagem de 430C (WELCH, 1967; VILLA \& ROA, 1979; PESKE \& BAUDET, 1980; CABELLO, 1982; PESKE \& AGUIRRE, 1987).

Conforme a direçå relativa de movimento das sementes e do ar no secador, a secagem de fluxo continuo pode ser classificada segundo três técnicas (KREIGER, 1973; LASSERAN, 1978; NELLIST, 1980): a) secagem concorrente. - o ar e as sementes avançam paralelamente, no mesmo sentido pelo interior do secador; b) secagem contracorrente, - a ar e as sementes movem-se paralelamente, mas em sentidos opostos, no interior do secador; c) secagem a corrente. cruzada. - o ar e as sementes deslocam-se em direçdes ortogonais dentro do secador.

Considerando a forma de atuaçao do ar aquecido, a secagem artificial pode ser dividida em dois tipos (ROSA, 1966; BROOKER et alii, 1974; TOLEDO \& MARCOS FILHO, 1977; PUZZI, 1986; DALPASQUALE et alii, 1987): a) secagem. continua. - as sementes ficam permanentemente sob a açăo do ar aquecido, até o seu teor de água atingir o valor desejado; b) secagem intermitente. - as sementes sao submetidas a açåo do ar aquecido durante intervalos regulares de tempo, intercalados por periodos sem aquecimento, denominados periodos de repouso ou equalizaçå. A intermitência permite que ocorra o transporte de água do interior para a superficie da semente durante o periodo de repouso, redu- 
zindo o gradiente de sua concentraçă, no interior do produto.

Edholm citado por HALL (1980) verificou que na secagem intermitente de sementes, empregando uma série de curtos periodos sob a açă de ar aquecido intercalados por longos periodos de repouso, a quantidade de água removida por unidade de tempo é consideravelmente maior do que na secagem continua, porque o limite máximo da velocidade de secagem, após a remoçăo da água da camada superficial da semente, é a velocidade de transporte da água do interior para a superficie.

Baseada na capacidade do ar fornecer calor e na necessidade de aumentar a temperatura do ar, a secagem artificial pode ser dividida em duas categorias (LASSERAN, 1980; MLLEAN, 1980; DALPASQUALE et alii, 1987; SODHA et alii, 1987): a) secagem em baixa temperatura. - utiliza-se ar natural ou aquecido de 1 a $80 \mathrm{C}$ acima da temperatura ambiente; b) secagem em alta temperatura. - consiste em aquecer o ar a temperaturas iguais ou superiores a 8-100 C acima da temperatura ambiente.

A combinaçă de um sistema em alta temperatura, até as. sementes alcançarem teores de água de 16 a 18\%, com um sistema em baixa temperatura para complementar a secagem, permite aumentar em 40 a $50 \%$ a capacidade dos equipamentos (LASSERAN, 1980; DALPASQUALE et alii, 1987).

${ }^{2}$ EDHOLM, H. Undersokningar angaende torkning av spanmal, s.n.t. 
A secagem de sementes de milho, pelo sistema em combinaça de alta e baixa temperaturas, resulta em menor susceptibilidade a quebra, maior porcentagem de germinaçao e menor desenvolvimento de fungos, quando comparada à secagem em alta temperatura (GUSTAFSON et alii, 1978; GUSTAFSON \& MOREY, 1979).

Na secagem de sementes de soja, em secador estacionário de fundo falso perfurado, BOYD (1974) verificou a necessidade de ajustar o fluxo de ar e a altura da camada de sementes, de forma a minimizar o tempo de secagem e reduzir os efeitos negativos sobre a qualidade da sementes. Constatou, também, que sementes colhidas com teores de água de 22,3 e $18,5 \%$ e secadas até $12 \%$, utilizando fluxos de ar iguais ou superiores a $10 \mathrm{~m} / \mathrm{min} / \mathrm{t}$ combinados com temperaturas do ar de 3800 , nao apresentaram reduçóes acentuadas na qualidade.

Mediante secador estacionário com distribuiçao radial de ar, CORREA (1981) procedeu a secagem de sementes de arroz, aliando temperatura do ar de $42^{\circ} \mathrm{C}$, espessura da camada de sementes de $1,35 \mathrm{~m}$ e tempos de secagem de 12 a 15 horas, nao observando prejuizos à sua qualidade fisiológica.

Os efeitos das danificaçôes térmicas e mecânicas em secadores, sobre a qualidade de sementes, têm sido pouco pesquisados nos sistemas de secagem intermitente. 
MIRANDA (1978) secando dois lotes de sementes de soja com teores iniciais de água de 17,5 e 15,4\%, em secador intermitente utilizando temperaturas do ar de 45 , 60 e 75॰C, nå observou prejuizos a qualidade fisiologica das sementes. Por outro lado, CAVARIANI (1983), estudando os efeitos da temperatura de secagem e dos danos mecânicos em um secador intermitente sobre a qualidade de sementes de soja, empregando temperaturas do ar de secagem de 50, 70 e $90 \circ \mathrm{C}$, concluiu que a temperatura do ar de $700^{\circ} \mathrm{e}$ a que menos afetou a qualidade da semente; a utilizaçao de ar aquecido à temperatura de $90^{\circ} \mathrm{C}$ provocou alta porcentagem de rachaduras no tegumento, enquanto a temperatura de $50 \circ \mathrm{C}$ ocasionou alta porcentagem de sementes partidas, em razao do excessivo número de passagens das sementes pelo sistema de secagem.

Ao secar sementes de arroz com teor inicial de água de 19,0 e $20,8 \%$, em secador intermitente utilizando temperaturas do ar de $60,70,80$ e 900C, R05A (1966) constatou que as temperaturas de 80 e $900 \mathrm{C}$ causaram reduçøes acentuadas na germinaçăo imediatamente após a secagem e que as temperaturas de 60 e $70 \circ \mathrm{C}$ nao ocasionaram efeitos imediatos e latentes sobre a sua qualidade fisiologica. Verificou, tambem, que a temperatura da massa de sementes atingiu no máximo $42,2^{\circ} \mathrm{C}$, utilizando ar aquecido a 700C, $\square$ que sugere a possibilidade de utilizaçăo desta temperatura sem prejudicar a sua qualidade fisiologica. Estes 
resultados foram corroborados por LUZ (1986) que, ao secar sementes de arroz em secador intermitente, utilizando temperaturas do ar de secagem de $70 \circ \mathrm{C}$ e variando o fluxo de ar, o teor de água inicial das sementes e o tempo de exposiça do ar aquecido, nao observou reduçoses significativas na germinaçăo e no vigor.

ROSA (1966) secando sementes de trigo pelo método intermitente, utilizando temperaturas do ar entre 40 e 1000C, em intervalos de looc, nao verificou efeitos imediatos e latentes da secagem sobre a germinaçă, nos lotes em que a temperatura esteve compreendida entre 40 e 800C; entretanto, observou reduçoses acentuadas no poder germinativo das sementes durante o armazenamento, quando secadas a 90 e $1000 \mathrm{C}$.

Durante a secagem, as sementes sofrem, simultaneamente, diversas mudanças fisicas, causadas por gradientes de temperatura e umidade que ocasionam estresses hidricos e térmicos, expansao, contraçă e alteraçăes na densidade e porosidade (FORTES \& OKOS, 1980).

o processo de secagem nao aumenta a porcentagem de sementes quebradas, mas pode provocar fissuras internas ou superficiais, tornando as sementes mais suscetiveis a quebra, durante o beneficiamento (GUSTAFSON et alii, 1978; GUSTAFSON \& MOREY, 1981).

A susceptibilidade à quebra é influenciada pelo teor de água e temperatura da semente, genótipo, es- 
pessura do endosperma córneo, temperatura do ar de secagem, método de secagem, velocidade de secagem, velocidade de resfriamento e tamanho e forma das sementes (GUSTAFSON et alii., 1978; GUSTAFSON \& MOREY, 1981; GUNASEKARAN \& PAULSEN, 1985; MOES \& VYN, 1988).

Atualmente pouco se conhece sobre as alteraçôes nos parâmetros fisicos e fisiológicos das sementes, durante o processo de secagem. Os danos termicos no processo de secagem de sementes de milho estão relacionados a alguns fatores, entre eles, genótipo, teor de água das sementes, temperatura de secagem, tempo de exposiçao e velocidade de secagem (NAVRATIL, 1980; BURRIS \& NAVRATIL, 1980; MEIER, 1983; NAVRATIL \& BURRIS, 1984; HERTER \& BURRIS, 1989a).

A utilizaçao de altas temperaturas durante a secagem pode causar reduçăo na porcentagem e velocidade de germinaçå, fissuras internas e/ou superficiais, plântulas anormais e, inclusive, a morte das sementes (HARRINGTON, 1972; NELLIST \& HUGUES, 1973).

A ocorrência de fissuras na cobertura protetora de sementes pode ocasionar a reduçao da capacidade de regulaçao de trocas hidricas e gasosas, o aumento da suscetibilidade à penetraçăo de microrganismos e insetos e a elevaçåo da sensibilidade aos efeitos fitotóxicos de fungicidas e inseticidas (MOORE, 1974; DHINGHA et alii, 1980; SOAVE \& MORAES, 1987; WETZEL, 1987; CARVALHO \& 
NAKAGAWA, 1988 ).

Elevadas temperaturas, muitas vezes, nåo causam reduçă imediata no poder germinativo, mas podem motivar reduçôes no vigor que, frequentemente, se manifestam durante o periodo de armazenamento ou na emergência das plântulas sob condiçaes adversas de ambiente ( NELLIST, 1980 ; POPINIGIS, 1985).

As sementes mais úmidas săo mais sensiveis aos danos térmicos; por isso, quanto mais elevado o teor de água, menor deve ser a temperatura empregada na secagem (HARRINGTON, 1972; POPINIGIS, 1985). Entretanto, segundo Washko = citado por HERTER (1987), o dano térmico ocorre durante a última fase da secagem, quando o teor de água da semente e a velocidade de secagem săo menores devido à reduçăo da velocidade de evaporaçăo e à elevaçăo da temperatura do embriao.

$\mathrm{Na}$ secagem de sementes de três linhagens de milho em espiga, em secador estacionário, empregando temperaturas do ar de secagem de 35, 40, 45 e 500C, NAVRATIL \& BURRIS (1984) verificaram que apenas as temperaturas de 45 e $50 \circ C$ afetaram de forma adversa a germinaçăo e o vigor das sementes, sendo o desenvolvimento radicular das plântulas mais suscetivel a danos térmicos, do que o desen-

2. WASHKO, J.B. The influence of artificial drying conditions on the viability and on the productivity of seed corn.Madison, 1941(Ph.D-University of Wisconsin). 
volvimento da parte aerea.

A tolerancia das sementes de milho ao dano térmico, durante a secagem artificial em altas temperaturas, apresenta grande variabilidade entre linhagens(NAVRATIL \& BURRIS, 1984; BDLIYA \& BURRIS, 1988), estando associada com a herança maternal e/ou citoplasmática (BDLIYA \& BURRIS, 1988).

A velocidade de secagem de sementes de milho em espiga é influenciada pela espessura e permeabilidade do pericarpo (PURDY \& CRANE, 1967), genotipo, maturidade da semente, teor de água da semente na colheita, diâmetro da espiga (CROSS, 1985) e espessura da camada de aleurona (TOTH \& SULLER, 1987 ).

Na avaliaçăo da qualidade de sementes de milho e de seu desempento, sob condiçôes de estresse, os testes de frio tem sido utilizados com freqüência. Em estudos de secagem, da mesma forma, tem sido empregados para avaliar as reduçôes na qualidade de sementes, associadas a secagem em altas temperaturas, tendo sido encontrada alta correlaçăo entre dano térmico $e$ a sensibilidade ao frio (NAVRATIL, 1980; LOEFFLER et alii, 1985). Há evidências de que a secagem em alta temperatura pode alterar a configuraçao básica das membranas celulares e, desse modo, reduzir a tolerância ao frio (BURRIS \& NAVRATIL, 1980).

A maioria dos sistemas subcelulares das se- 
mentes, inclusive o genoma, podem ser danificados durante a secagem (ROBERTS, 1981), send̦o a desorganizaçăo do sistema de membranas celulares, a primeira consequência do dano térmico (DANIELL et alii, 1969). Reduçoes na qualidade fisiológica de sementes sao, em geral, acompanhadas do aumento na liberaça de eletrólitos e açúcares pelas sementes embebidas em água, sugerindo mudanças deteriorativas nas membranas celulares (PARRISH \& LEOPOLD, 1978).

Em sementes de milho, elevadas temperaturas de secagem podem causar a hidrólise dos gráos de amido, reduzindo seu número e tamanho no eixo embrionário, durante os primeiros estádios do processo de secagem. A maior condutividade eletrica dos exsudatos das sementes secadas a elevadas temperaturas, comparado com as secadas a baixas temperaturas, pode ser um indicativo do aumento da permeabilidade das membranas, levando a crer que os danos térmicos podem ser atribuidos a mudanças deletérias nas membranas celulares (SEYEDIN et alii, 1984). Por outro lado, HERTER \& BURRIS (1989b) sugeriram que o aumento da permeabilidade das membranas seria apenas um dos fatores responsáveis pelo dano térmico, podendo a integridade do pericarpo, pọr exemplo, afetar a condutividade elétrica dos exsudatos liberados pelas sementes de milho.

No processo de secagem, a temperatura alcançada pela semente e o tempo de exposiçăo a essa temperatura sao os principais fatores que, potencialmente, podem 
afetar a qualidade das sementes. Dependendo do método de secagem, é possivel utilizar altas temperaturas do ar, desde que a temperatura da massa de sementes seja mantida dentro de limites seguros. Em secadores intermitentes, as sementes atingem temperaturas inferiores a do ar de secagem, em virtude da existência do periodo de repouso em que nåo eståo sob a açăo do ar aquecido e do prazo de exposiçăo ao ar aquecido, o que sugere a possibilidade de conduzir a secagem em altas temperaturas, sem ocasionar reduçôs na qualidade das sementes. 


\section{MATERIAL E MÉtOdOS}

o presente trabalio, conduzido experimentalmente no periodo de abril a novembro de 1989 , foi realizado na Unidade de Beneficiamento ISanta Cruz das Palmeiras/SP) da empresa Sementes Agroceres S.A. e nos Laboratórios de Análise de Sementes e de Patologia de Sementes, respectivamente pertencentes aos Departamentos de Agricultura e de Fitopatologia da Escola Superior de Agricultura "Luiz de Queiroz"/USP (Piracicaba/SP).

Foram utilizados três lotes ( $A$, B e C) de sementes de milho, do hibrido duplo AG-162, grupo dentado amarelo, produzidos na safra 1988/1989, pela empresa Sementes Agroceres S.A., Unidade de Santa Cruz das Palmeiras, SP.

Após a colheita, em 20 de abril de 1989, as sementes foram imediatamente transportadas, a granel, para a Unidade de Beneficiamento de Sementes, onde procedeu-se à pré-limpeza e à secagem.

A pré-limpeza foi realizada em uma máquina de ventilador e peneiras marca CWA, com duas peneiras e uma coluna de ar, aproveitando-se as sementes que passaram 
através das perfuraçôes da peneira superior (10 × $19 \mathrm{~mm})$ e deslizaram sobre a peneira inferior $(4,8 \mathrm{~mm})$.

0 sistema de secagem utilizado empregou um secador de fluxo continuo, adaptado para operar na forma intermitente, da marca D'Andréa, modelo D-200, com capacidade estática efetiva de $27 \mathrm{t}$, equipado com uma formaliha metálica de calor irradiado (fogo indireto) e um elevador duplo de caçambas de $20,0 \mathrm{~m}$ de altura, com as seguintes caracteristicas adicionais:

- capacidade estática total: $36 \mathrm{~m}^{3}$

- capacidade da câmara de repouso: 16 m:

- capacidade da câmara de secagem: $14 \mathrm{~m}^{3}$

- capacidade de câmara de resfriamento: $6 \mathrm{~m}$ : Operacionalmente, o equipamento foi regulado para atender ao seguinte esquema de trabalino:

- fluxo de ar na câmara de secagem:300m:3/min

- tempo de exposição das sementes ao ar aquecido por ciclo no sistema de secagem: $35 \mathrm{~min}$

- periodo de equalização: 55 min

- relaçå aproximada de intermitência (aquecimento/sem aquecimento): 1:1,6

- tempo de descarga: $90 \mathrm{~min}$

\subsection{Obtençåo dos tratamentos}

Foram realizados três Estudos denominados 1, 2 e 3,utilizando, respectivamente, os lotes $A, B$ e $C$. 
o Estudo 1 envolveu os seguintes tratamentos de secagem:

a) secagem natural (tratamento $S N$ ): durante a operaçă de carregamento do secador, retiraram-se quatro amostras que, a seguir, foram expostas ao sol, em camadas de espessura aproximada de $10 \mathrm{~cm}$; durante $16 \mathrm{~h}$; as sementes sofreram movimentaçao freqüente até atingirem teores de água de 12 a $13 \%$;

b) secagem artificial-natural (tratamento SAN): a carga de secador foi submetida a secagem intermitente, com temperatura do ar de $70^{\circ} \mathrm{C}$, medida no duto de entrada de ar aquecido, até as sementes alcangarem o teor de água de 15\%; nesta ocasiao retiraram-se quatro amostras, que foram expostas ao sol, durante $12 \mathrm{~h}$; até as sementes apresentarem teores de água de 12 a $13 \%$;

c) secagem artificial (tratamento SA): o restante da carga que permaneceu no secador passou por secagem intermitente a temperatura do ar de $70^{\circ} \mathrm{C}$, até teores de água de 12 a $13 \%$, retirando-se, ao final, quatro amostras.

As amostras obtidas mos tratamentos SAN e SA foram retiradas na extremidade posterior da calha vibratória da descarga do secador, mantendo um intervalo de tempo de 2 min entre a retirada de duas amostras consecutivas.

0 peso de cada uma das amostras coletadas 
nos três tratamentos foi de $5 \mathrm{~kg}$.

Nos três tratamentos de secagem, as amostras retiradas constituiram as repetiçôes.

Os Estudos 2 e 3 foram conduzidos similarmente ao Estudo 1, com exceção das temperaturas do ar empregadas na secagem intermitente, nos tratamentos SAN e SA que foram, respectivla-mente, de 80 e 90ㄷ.

Visando a uniformizaçăo do teor de água das sementes, após a obtençăo dos tratamentos de secagem, as amostras foram expostas ao sol, durante oh.

\subsection{Armazenamento das sementes}

Após a secagem, cada amostra de sementes foi acondicionada em embalagem permeável de papel multifoliado, tipo kraft 80 (80 $\left.\mathrm{g} / \mathrm{m}^{\mathrm{I}}\right)$, com capacidade de $5 \mathrm{~kg}$ e colocada em condiçôes nåo controladas de ambiente em uma sala do Laboratório de Análise de Sementes do Departamento de Agricultura (LAS/LAG), permanecendo armazenada por um periodo de seis meses.

As temperaturas máximas, médias e minimas do ar e as umidades relativas do ar médias foram monitoradas durante o periodo de armazenamento.

o periodo de armazenamento teve inicio cinco dias após a colneita e a coleta de amostras para a 
avaliaçăo da qualidade das sementes, foi realizada a cada 60 dias, conforme a seguinte. indicaçăo:

$\begin{array}{cc}\text { Epoca } & \text { Prazo de armazenamento(dias) } \\ E_{2} & 0 \\ E_{2} & 60 \\ E_{3} & 120 \\ E_{4} & 180\end{array}$

Aos 120 dias de armazenamento, àntes da terceira época de coleta de amostras, as sementes foram tratadas com fosfina, aplicando-se um comprimido de fosfeto de aluminio de $0,6 \mathrm{~g}$ para $120 \mathrm{~kg}$ de sementes, durante $72 \mathrm{~h}$, seguindo recomendaçăo de BITRAN (1989).

\subsection{Determinaçđ̆es durante a secagem intermitente}

Durante a secagem intermitente, em intervalos regulares de $30 \mathrm{~min}$, foram retiradas quatro amostras e acondicionadas em recipientes a prova de vapor dágua (lata vedada), completamente cheios, para a posterior determinaçao do teor de água das sementes, em laboratório.

o monitoramento do teor de água das sementes, durante a secagem intermitente foi realizado através de um determinador tipo Steinlite.

Concomitantemente, as seguintes determinaçôes foram realizadas: 
a) Temperatura do ar de secagem - determinada através de um termômetro analógico, localizado no duto de entrada do ar aquecido no secador.

b) Temperatura da massa de sementes na câmara de secagem - determinada através de um termômetro analógico, localizado na parte inferior da câmara de secagem do secador.

c) Temperatura da massa de sementes na saida do secador - amostras foram coletadas na extremidade posterior da calha vibratória da descarga do secador e colocadas em recipientes semi-adiabáticos (caixas de isopor), sendo a temperatura medida por um termômetro de bulbo, acoplado perpendicularmente à tampa do recipiente e mantido na massa de sementes por um periodo de 2 minutos.

d) Umidade relativa do ar e temperatura ambiental - determinadas através de um psicrômetro, instalado nas imediaçóes do ponto de coleta do ar pelo secador durante o processo de secagem.

\subsection{Determinaçôes de laboratório}

Para avaliar os lotes qualitativamente, foram realizadas as seguintes determinaçöes:

a) Determinaçăo do teor de água - Realizada em estufa elétrica de desidrataçăo, sem ventilaçăo forçada, utilizando-se o método de estufa a $105 \circ C \pm 3$ oC, durante 
24 horas, conforme prescriçao, para a determinaçao do teor de umidade, das Regras para Análise de Sementes (BRASIL, Ministério da Agricultura, 1980). Foram utilizadas duas amostras com $30 \mathrm{~g}$ de sementes cada uma e o teor de água foi expresso em porcentagem em base úmida.

b) Teste de germinaçăo - Conduzido de acordo com as prescriçaes das Regras para Análise de Sementes (BRASIL, Ministério da Agricultura, 1980), com exceçao do número de sementes, que foi de 200 sementes, dividido em quatro repetiçoes iguais. 0 substrato utilizado foi papel toalha, marca Germitest e o germinador regulado para temperaturas alternadas de $20-30 \circ \mathrm{C}$.

c) Teste de envelhecimento rápido - Executado conforme metodologia proposta pela ASSOCIATION OF OFFICIAL SEED ANALYSTS (1983) e tambem descrita por MARCOS FILHO et alii (1987), consistiu na utilizaça de caixas "gerbox", como compartimento individual (mini-camaras), possuindo em seu interior uma bandeja de tela de aluminio, onde as sementes foram distribuidas. No fundo, de cada minicâmara, foram depositados $40 \mathrm{ml}$ de água e, em seguida, os gerbox foram mantidos em estufa incubadora, regulada a temperatura de 420C, por um periodo de 96 horas. Apds esse periodo de permanência na estufa incubadora, as sementes foram submetidas ao teste de germinaçao, conforme descrito no item b, utilizando-se 200 sementes, divididas em 4 repetiçoes iguais por amostra, sendo a interpretaçăo executada 
após 4 dias de permanência no germinador.

d) Teste de frio sem solo - Conduzido com 4 repetiçores de 50 sementes, por amostra, semeadas em rolos de papel toalha, marca Germitest. Os rolos foram colocados em caixas plásticas (18 cm $\times 25 \mathrm{~cm} \times 10 \mathrm{~cm}$ ) que, tampadas e seladas, permaneceram em câmara regulada a 130C, por um periodo de 7 dias ( $168 \mathrm{~h})$. Após este periodo, os rolos foram mantidos em germinador regulado para temperaturas alternadas de 20-300C, sendo a interpretaça realizada após 4 dias de permanência no germinador.

e) Exame de sementes infestadas - realizado com duas repetiçöes de 100 sementes por amostra, imersas em água por um periodo de 18 horas e, a seguir seccionadas longitudinalmente. As sementes foram examinadas individualmente, considerando-se atacadas aquelas que apresentavam ovo, lagarta, pupa, inseto adulto e/ou o orificio de saida do inseto, conforme as prescriçöes das Regras para Análise de Sementes (BRASIL, Ministério da Agricultura, 1980) .

f) Teste de sanidade - Conduzido com 200 sementes distribuidas em quatro repetiçoes iguais por amostra, colocadas em placas de Petri, contendo três fol has de papel de filtro. Após a instalaçao, as sementes foram mantidas por 24 horas em câmara de incubaçao à temperatura de $200 \mathrm{C} \pm 20 \mathrm{C}$, sob regime de 12 horas de luz e 12 horas de escuro. A seguir, as sementes permaneceram em congelador a 
temperatura de $-14 \circ \mathrm{C}$, por um periodo de 24 horas. Depois, as sementes retornaram à câmara de incubaçăo, permanecendo por mais 6 dias. A interpretaçao foi realizada com auxilio de microscopio estereoscópico elou microscópio composto, conforme descrito por LUCCA FILHO (1987) e MENTEN (1988).

g) Teste de coloraça de tintura de iodo Executado com duas amostras de 100 sementes, colocadas em copos de plástico e, a seguir, cobertas com uma soluçăo de tintura de iodo a $4 \%$, por um periodo de 5 minutos. Em seguida, eliminando o excesso de soluçao, as sementes foram distribuidas sobre folhas de papel toalha para a contagem do número de sementes danificadas, conforme descrito por MARCOS FILHO et alii (1987). Os resultados foram expressos em porcentagem de sementes danificadas por amostra.

h) Exame de sementes com dano mecânico visivel - Realizado com duas repetiç8es de $100 \mathrm{~g}$ de sementes por amostra, retiradas da fraça semente pura, apos a análise de pureza. As sementes foram examinadas individualmente com auxilio de uma lupa de aumento $(10 x)$ e classificadas em sementes com e sem dano mecânico visivel. Us resultados foram expressos em porcentagem em peso de sementes com dano mecânico visivel.

i) Determinaçăo do total de impurezas - Foi conduzida através da análise de pureza fisica, segundo as Regras para Análise de Sementes (BRASIL, Ministério da Agricultura, 1980). 0 peso total de impurezas foi 
determinado pela soma dos pesos do material inerte e de outras sementes. Os resultados foram expressos em porcentagem em peso de impurezas por amostra.

Para a caracterizaçăo qualitativa dos lotes foram realizadas as seguintes determinaçöes: teor de água, teste de germinaçăo, teste de envelhecimento rápido, teste de frio sem solo,exame de sementes infestadas, teste de sanidade, teste de coloraçăo de tintura de iodo, exame de sementes com dano mecânico visivel e determinaçăo do total de impurezas.

Durante o periodo de armazenamento, nas quatro epocas, foram conduzidos testes de germinaçăo, envelhecimento rápido, frio sem solo e determinaçao do teor de água das sementes.

Na primeira e quarta épocas, tambem foram realizados 0 teste de sanidade e 0 exame de sementes infestadas. Para a identificaçăo de sementes com danos mecânicos, na primeira época, foram conduzidos o teste de coloraçăo com tintura de iodo, o exame de sementes com dano mecânico visivel e a determinaça do total de impurezas.

\subsection{Determinaçåo de campo}

a) Emergência em campo - Realizada com 200 sementes, distribuidas em quatro repetiçöes; dessa forma, cada repetiçăo, constituida por uma linha de $5 \mathrm{~m}$, recebeu a 
colocaçao de 50 sementes. O espaçamento entre as linhas foi de $0,30 \mathrm{~m}$. A contagem do número de plantas emersas foi efetuada aos 14 dias após a semeadura, na primeira e na quarta epocas experimentais.

\subsection{Métodos estatisticos}

A análise estatistica dos dados foi-realizada, no Sistema de Análise Estatistica para Microcomputadores - SANEST (ZONTA et alii, 1984), separadamente, para cada um dos Estudos conforme a descriçao que se segue.

As curvas de secagem foram determinadas

atraves do ajustamento de curvas de regressao polinomial, relacionando-se o comportamento do teor de água das sementes e o tempo decorrido durante o processo de secagem.

Os dados dos testes de germinaça, envelhecimento rápido, frio sem solo e teor de água foram analisados segundo um esquema de parcelas subdivididas em delineamento inteiramente casualizado, com 4 repetiçoes, sendo a análise da variancia realizada de acordo com o esquema mostrado na Tabela 1. Os dados de porcentagem de germinaça, envelhecimento rápido e frio sem solo foram transformados em arc sen $\sqrt{\text { porcentagem/100. }}$ 
Tabela 1 - Esquema da análise da variância dos dados de germinaçăo, envelhecimento rápido, frio sem solo e teor de água.

Causas da variaçăo

Graus de liberdade

Tratamentos de secagém (T)

2

Residuo a

9

Parcela

11

Epocas ( $E$ )

3

Interaçå $T \times E$

6

Residuo b

27

Total

47

Os dados do teste de sanidade, emergência em campo e exame de sementes infestadas foram analisados segundo um esquema fatorial $3 \times 2$, em delineamento inteiramente casualizado, com 4 repetiçoes, e a análise de variância foi realizada segundo o esquema mostrado na Tabela 2.

Os dados dos testes de sanidade e emergência em campo foram transformados em arc sen $\sqrt{\text { porcentagem/100 }}$ e os do exame de sementes infestadas foram transformados em $\sqrt{x+0,5}$

Os dados do teste de coloraçao de tintura de iodo,exame de sementes com dano mecânico visivel e determinaçao do total de impurezas foram analisados segundo um delineamento inteiramente casualizado, com 8 repetiçôes, sendo 
a análise da variancia conduzida conforme o esquema mostrado na Tabela 3.0 s dados do.teste de coloraçao de tintura de iodo foram transformados em arc sen $\sqrt{\text { porcentagem/100. }}$

Tabela 2 - Esquema da análise da variancia dos dados do teste de sanidade, exame de sementes infestadas e emergência em campo.

Causas da variação

Graus de liberdade

$\begin{array}{lr}\text { Tratamentos de secagem (T) } & 2 \\ \text { Épocas (E) } & 1 \\ \text { Interaçao T } T \text { E } & 2 \\ \text { Residuo } & 18\end{array}$

Total

23

Para todas as determinaçôes foram realizadas as comparaçôes entre médias empregando o teste de Tukey, ao nivel de $5 \%$ de probabilidade.

Tabela 3 -Esquema da análise da variância dos dados do teste de coloraçao de tintura de iodo, exame de sementes com dano mecânico visivel e determinaçă do total de impurezas.

Causas de variaçăo

Graus de liberdade

Tratamentos de secagem

Residuo 


\section{RESULtAdOS E discussão}

Embora os dados obtidos nos testes de germinaçăo, envelhecimento rápido, frio sem solo, emergência em campo, sanidade, coloraçao de tintura de iodo e no exame de sementes infestadas tenham sido transformados para a realizaçăo da análise estatistica, os resultados foram apresentados por meio de médias dos dados originais, com a finalidade de facilitar a visualizaçao e a interpretaçăo dos parâmetros avaliados.

\subsection{Caracterizaçăo dos Lotes}

Este procedimento teve por objetivo a detecçă de possiveis diferenças qualitativas entre os lotes $A$, B e C, utilizados nos estudos 1,2 e 3 , respectivamente.

Os dados obtidos såo apresentados na Tabela 4. Verificam-se resultados similares, entre os lotes, nos testes de germinaçă, de frio sem solo, de emergência em campo, nos exames de sementes infestadas e de sementes com dano mecânico visivel e nas determinaçoes do teor de água e do total de impurezas. Algumas diferenças, no teste de coloraçăo de tintura de iodo e na incidencia de Penicillium spp., podem ser observadas entre o lote $A$ e os demais. 
Tabela 4. Caracterizaçăo da qualidade inicial das sementes de milho, dos lotes $A$, B e C.

Determinaçछes (\%)

\section{Lotes}

A

B

C

\begin{tabular}{lccc}
\hline Teor de água & 16,5 & 15,8 & 15,9 \\
Teste de germinaça & 95 & 95 & 95 \\
Teste de envelhecimento rápido & 83 & 85 & 90 \\
Teste de frio sem solo & 92 & 92 & 92 \\
Exame de sementes infestadas & 0,8 & 0,5 & 0,9 \\
Incidência de Penicillium spp. & 88 & 95 & 98 \\
Incidência de Aspergillus spp. & 12 & 11 & 9 \\
Incidência de F. moniliforme & 8 & 13 & 42 \\
Incidência de Cephalosporium spp. & 41 & 48 & 96 \\
Emergência em campo & 94 & 95 & 17,0 \\
TCTİ & 20,7 & 16,4 & 7,5 \\
Esdmuz & 7,2 & 7,6 & 2,0 \\
DTI: & 2,1 & 2,2 & 9 \\
\hline
\end{tabular}

1 TCTI = Teste de coloraçao de tintura de iodo

I ESDMV = Exame de sementes com dano mecanico visivel

= DTI = Determinaçăo do total de impurezas

A menor incidência de Aspergillus spp. e o maior valor obtido no teste de envelhecimento rápido verificou-se no lote C em relaçăo aos lotes A e B. O lote B, 
por sua vez, apresentou incidencia mais elevada de Cephalosporium spp. e Fusarium moniliforme do que os lotes $A \in C$.

Năo obstante as diferenças verificadas em determinados testes, pode ser afirmado que, em linhas gerais, os lotes eram qualitativamente semelhantes.

\subsection{Curvas de secagem}

Os dados relativos as determinaçöes efetuadas durante a secagem intermitente, a temperatura do ar de 700C, săo apresentados na Tabela 5 (Estudo 1).

Tabela 5. Dados referentes as determinaçoses realizadas durante a secagem intermitente das sementes de milho empregando ar de secagem a temperatura de 700C (Estudo 1 ).

\begin{tabular}{|c|c|c|c|c|c|c|}
\hline \multirow{2}{*}{$\begin{array}{l}\text { Tempo } \\
\text { de } \\
\text { secagen } \\
\text { (nin) }\end{array}$} & \multicolumn{2}{|c|}{ Ambiente } & \multirow{2}{*}{$\begin{array}{l}\text { Tenperatnra } \\
\text { do ar de } \\
\text { secagearoc) }\end{array}$} & \multicolumn{2}{|c|}{ Tenperatura das senentes } & \multirow{2}{*}{$\begin{array}{l}\text { Teor de } \\
\text { agna das } \\
\text { sementes } \\
(\%)\end{array}$} \\
\hline & $\begin{array}{l}\text { Temperatura } \\
(0,)^{2}\end{array}$ & Un. re lativa & & $\begin{array}{l}\text { Cimara de } \\
\text { secage }(o f)\end{array}$ & $\begin{array}{l}\text { Saida do } \\
\text { secador }(0 \mathrm{C})\end{array}$ & \\
\hline 8 & 26,7 & 64 & - & 26 & 26 & 16,5 \\
\hline 38 & 25,0 & 68 & 71 & 32 & 28 & 15,9 \\
\hline 60 & 24.4 & 67 & 70 & 32 & 29 & 15,5 \\
\hline 30 & 23,0 & 70 & 70 & 34 & 29 & 15,2 \\
\hline 120 & 22,8 & 68 & 71 & 34 & 30 & 15,8 \\
\hline 150 & 22,8 & 70 & 71 & 35 & 31 & 14,8 \\
\hline 180 & 22,3 & 68 & 70 & 35 & 31 & 14,6 \\
\hline 210 & 21,7 & 69 & 72 & 34 & 30 & 14,4 \\
\hline 249 & 20,6 & 70 & 71 & 35 & 31 & 14,2 \\
\hline 270 & 29,2 & 69 & 70 & 35 & 30 & 13,8 \\
\hline 300 & 29,0 & 78 & 68 & 35 & 31 & 13,2 \\
\hline Mèdia & 22.7 & 69 & 70 & - & - & - \\
\hline
\end{tabular}


A temperatura média do ar de secagem alcan-

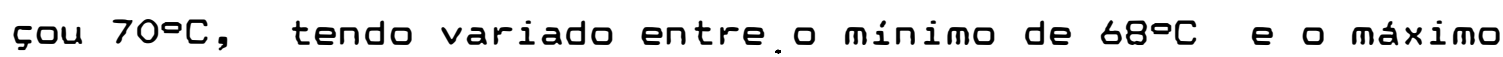
$72^{\circ} \mathrm{C}$, enquanto a temperatura do ar ambiente variou entre 20,0 e 26,70C, sendo a média 22,70C. Desta forma, o aquecimento do ar para a realizaçao da secagem demandou a elevaça média de $470 \mathrm{C}$, na temperatura do ar ambiente. Esta alteraçao, aplicada em gráfico psicrométrico, para pressao atmosferica de $760 \mathrm{~mm}$ de mercúrio (LASSERAN, 1978 e PESKE \& AGUIRRE, 1987), considerando a umidade relativa to ar inicial de $69 \%$, permitiu concluir que o ar aquecido passou a apresentar a umidade relativa de $7 \%$.

As temperaturas da massa de sementes na câmara de secagem e na saida do secador atingiram, respectivamente, 35 e $310 \mathrm{C}$, após $150 \mathrm{~min}$ de secagem, mantendo-se, a partir dai, praticamente invariáveis em funçå do tempo, até o final do processo.

A Figura 2 representa o comportamento do teor de água das sementes em funça do tempo, na secagem intermitente, à temperatura do ar de $70 \circ \mathrm{C}$.

A relaçå entre a reduça do teor de água das sementes e o tempo de secagem foi representada por uma equaça de primeiro grau, capaz de explicar 94,35\% da variaço. Entre os teores de água de 16,5 e $13,2 \%$, a velocidade de secagem permaneceu constante em $0,52 \% / h$. 


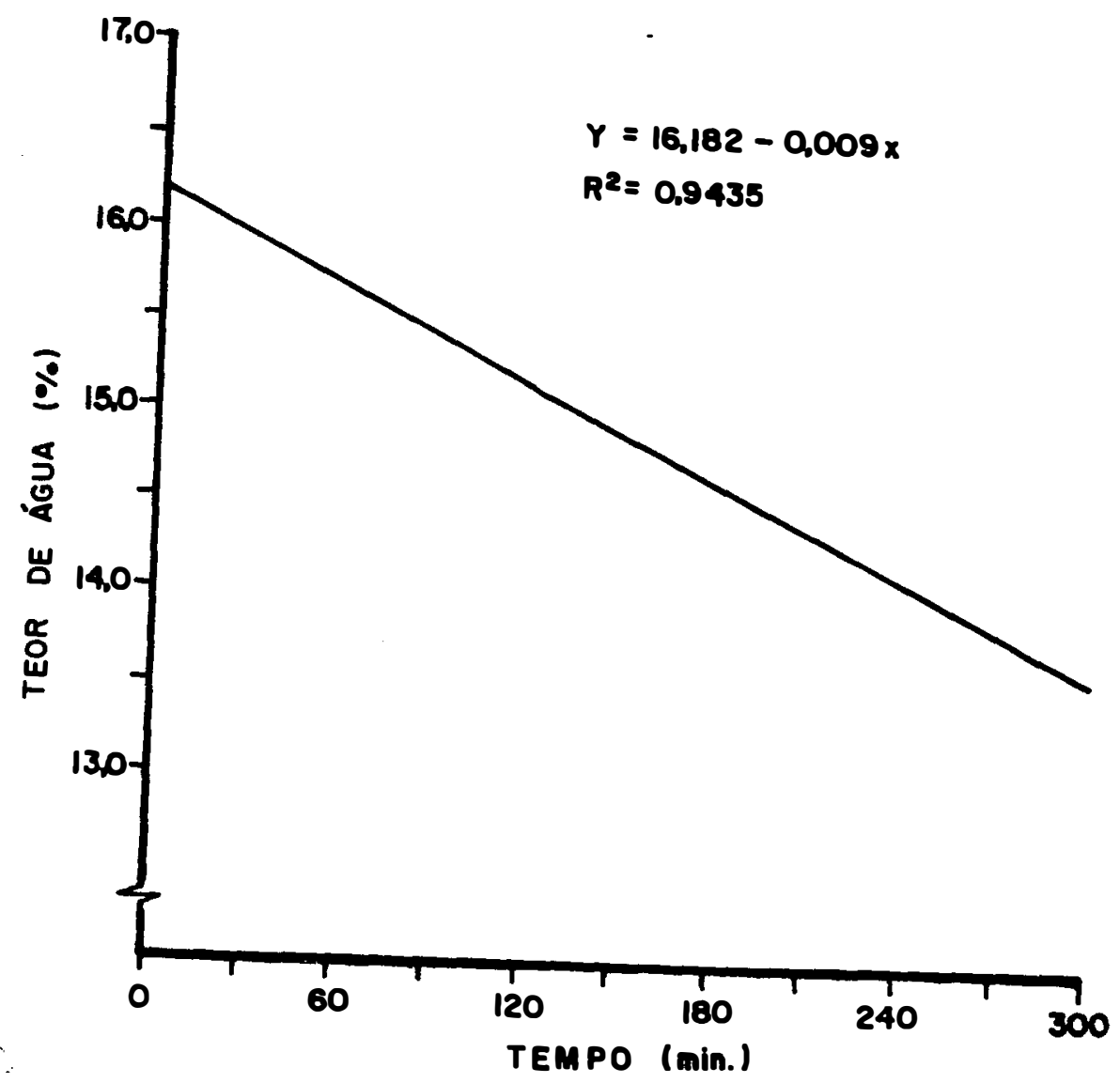

Figura 2 - Curva de secagem representando o comportamento do teor de água das sementes de milho em funçao do tempo. Secagem intermitente à temperatura do ar de $70 \circ \mathrm{C}$ ( Estudo 1).

A Tabela ó mostra os dados concernentes ás determinaçôes conduzidas durante a secagem intermitente a temperatura do ar de 800C (Estudo 2). 
Tabela 6. Dados referentes as determinaçoes realizadas durante a secagem intermitente das sementes de milho empregando ar de. secagem a temperatura de $80^{\circ} \mathrm{C}$ (Estudo 2).

\begin{tabular}{|c|c|c|c|c|c|c|}
\hline \multirow{2}{*}{$\begin{array}{l}\text { Tempo } \\
\text { de } \\
\text { secagen } \\
\text { (gin) }\end{array}$} & \multicolumn{2}{|c|}{ Alsbiente } & \multirow{2}{*}{$\begin{array}{l}\text { Tenperatara } \\
\text { do ar de } \\
\text { secagen }(O C)\end{array}$} & \multicolumn{2}{|c|}{ Tenperatira das senentes } & \multirow{2}{*}{$\begin{array}{l}\text { Teor de } \\
\text { agea das } \\
\text { sementes } \\
(\%)\end{array}$} \\
\hline & $\begin{array}{c}\text { Temperatura } \\
(O C)\end{array}$ & Un. re lativa & & $\begin{array}{l}\text { camara de } \\
\text { secageu (oc) }\end{array}$ & $\begin{array}{l}\text { Saida do } \\
\text { secador( } 0 \text { C })\end{array}$ & \\
\hline 8 & 26.7 & 66 & - & 26 & 26 & 15,8 \\
\hline 30 & 22.7 & 66 & 78 & 32 & 27 & 15,5 \\
\hline 60 & 28,0 & 65 & 83 & 37 & 30 & 15,1 \\
\hline 90 & 24,4 & 72 & 82 & 38 & 31 & 14,8 \\
\hline 120 & 23,3 & 74 & 80 & 38 & 31 & 14,6 \\
\hline 150 & 24,1 & 75 & 79 & 39 & 32 & 14,5 \\
\hline 180 & 23,3 & 76 & 88 & 38 & 31 & 14,1 \\
\hline 210 & 23,4 & 76 & 78 & 39 & 32 & 13,6 \\
\hline 240 & 23,5 & 77 & 79 & 39 & 32 & 13,1 \\
\hline Média & 24,6 & 72 & 80 & - & - & - \\
\hline
\end{tabular}

A temperatura média do ar ambiente verificada, foi de $24,6 \circ \mathrm{C}$, tendo variado de 28,0 a 23,3 or e a temperatura média do ar de secagem chegou a $80^{\circ} \mathrm{C}$, com variaçoes entre 78 e $83^{\circ} \mathrm{C}$. A umidade relativa do ar de secagem atingiu, conforme gráfico psicrométrico (LASSERAN, 1978), o valor de 5\%, determinado pelo acréscimo de 550C na temperatura do ar ambiente, cuja umidade relativa média era de $72 \%$.

A temperatura da massa de sementes na câmara de secagem estabilizou-se em $390 \mathrm{C}$ e, na saida do secador, em $32^{\circ} \mathrm{C}$, decorridos $150 \mathrm{~min}$ de secagem, sofrendo, assim, 
uma reduça de 70C ao atravessar a camara de resfriamento.

Na Figura 3 oḅserva-se que o teor de água das sementes decresceu de forma linear com o tempo, no decorrer da secagem intermitente, a temperatura do ar de 80०C, sendo que a funçăo linear tem a possibilidade de justificar 93,97\% da variaçăo. A diminuiçăo do teor de água das sementes por unidade de tempo manteve-se invariável em $0,66 \% / h$, para teores entre 15,8 e $13,1 \%$.

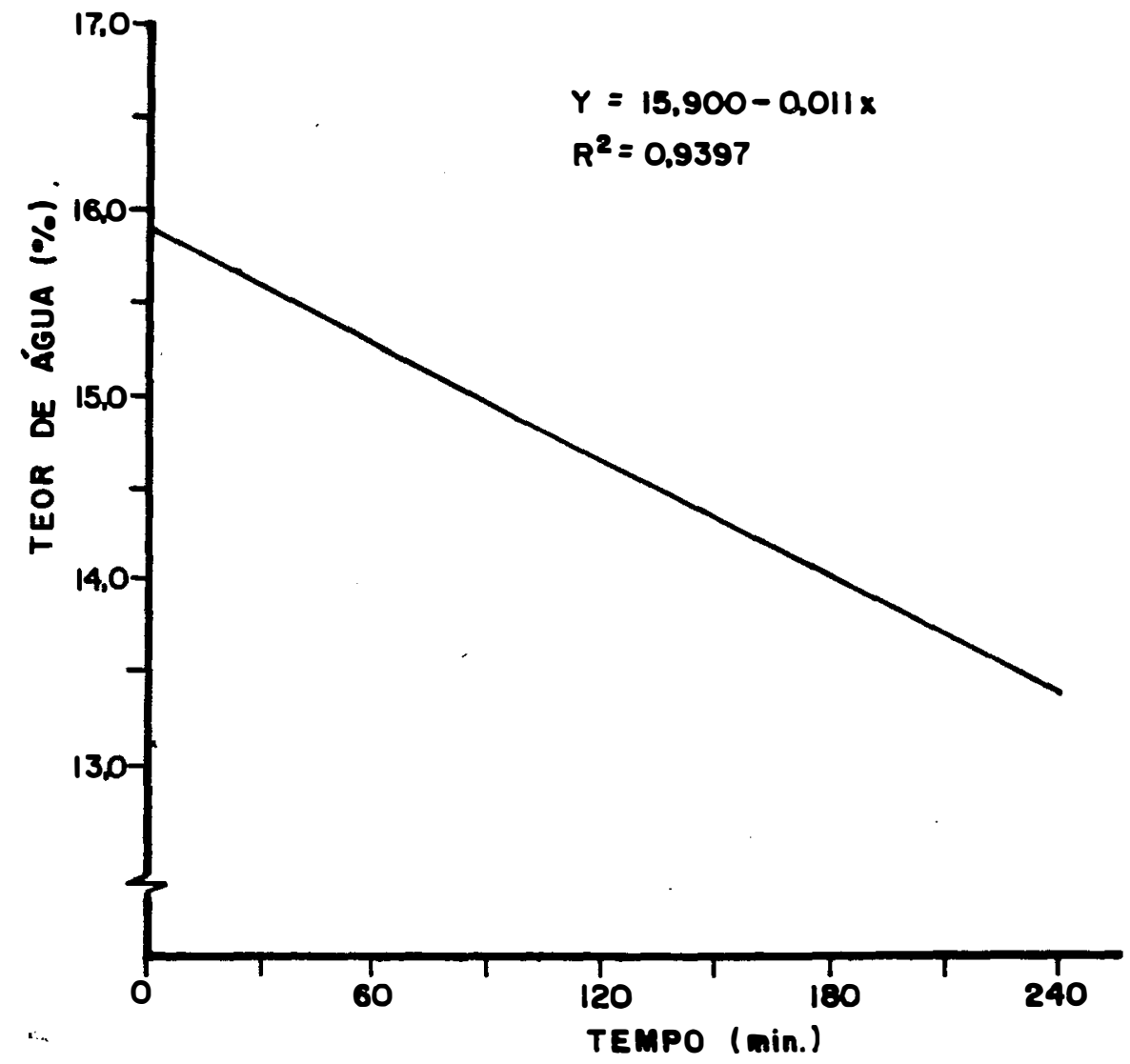

Figura 3 - Curva de secagem representando o comportamento do teor de água das sementes de milho em funçăo do tempo. Secagem intermitente à temperatura do ar de $80 \circ \mathrm{C}$ (Estudo 2). 
A Tabela 7 revela os dados referentes às determinaçóes levadas a efeito, no transcurso da secagem intermitente, a temperatura do ar de 900C (Estudo 3 ).

Tabela 7. Dados referentes as determinaçós realizadas durante a secagem intermitente das sementes de milho empregando ar de secagem a temperatura de $90^{\circ} \mathrm{C}$ (Estudo 3).

\begin{tabular}{|c|c|c|c|c|c|c|}
\hline \multirow{2}{*}{$\begin{array}{l}\text { Tenpo } \\
\text { de } \\
\text { secagen } \\
\text { (rin) }\end{array}$} & \multicolumn{2}{|c|}{ Ambiente } & \multirow{2}{*}{$\begin{array}{l}\text { Teliperatura } \\
\text { do ar de } \\
\text { secagenfoc })\end{array}$} & \multicolumn{2}{|c|}{ Temperatura das selientes } & \multirow{2}{*}{$\begin{array}{l}\text { Teor de } \\
\text { agea das } \\
\text { segentes } \\
(\%)\end{array}$} \\
\hline & $\begin{array}{l}\text { Tenperatira } \\
(0 C)\end{array}$ & Uni.relativa & & $\begin{array}{l}\text { Caliara de } \\
\text { secageni (oc) }\end{array}$ & $\begin{array}{l}\text { Saida do } \\
\text { secadorfoc) }\end{array}$ & \\
\hline 6 & 28,8 & 76 & - & 23 & 23 & 15,9 \\
\hline 30 & 23,4 & 74 & 86 & 34 & 28 & 15,5 \\
\hline 60 & 24,2 & 74 & 92 & 37 . & 32 & 15,0 \\
\hline 90 & 25,0 & 72 & 94 & 38. & 33 & 14,7 \\
\hline 120 & 25,3 & 39 & 98 & 39 & 35 & 14,4 \\
\hline 150 & 25,6 & 68 & 92 & 40 & 36 & 14,1 \\
\hline 180 & 26,5 & 68 & 88 & 41 & 37 & 13,5 \\
\hline 210 & 27,4 & 66 & 98 & 41 & 37 & 13,0 \\
\hline Média & 25,5 & 71 & 90 & - & - & - \\
\hline
\end{tabular}

A temperatura média do ar de secagem alcançou 900C, tendo sofrido variaçôes entre 86 e 940C, ao passo que a temperatura média do ar ambiente foi de 25,00C, variando entre o minimo de $22,8 \circ \mathrm{C}$ e o máximo de $27,4 \circ \mathrm{C}$. Com a elevaçao da temperatura média do ar de 250C para 900C, a umidade relativa média do ar sofreu uma reduça de $71 \%$ para $3 \%$, conforme gráfico psicrometrico (LASSERAN, 1978) e 
desta maneira, aumentou, de forma acentuada, sua capacidade de retençao de água.

A massa de sementes na camara de secagem atingiu a temperatura máxima de $41^{\circ} \mathrm{C}$, enquanto que na saida do secador chegou a $37^{\circ} \mathrm{C}$, mantendo uma diferença de temperatura de 40 entre estes pontos; esta diferenca foi igualmente manifestada na secagem a temperatura do ar de $70 \circ$ C (Estudo 1).

A Figura 4 expressa, através de uma equaça de primeiro grau, a curva de secagem de sementes de milho, empregando o método intermitente a temperatura do ar de 900C, representativa de 96,95\% da variaço. Para teores de água entre 15,9 e $13,0 \%$, a velocidade de secagem conservou-se constante em $0,79 \% / h$.

o aumento da temperatura do ar reduziu o tempo de secagem, nåo ocorrendo, entretanto, na mesma proporço. A elevaça na temperatura de 700C para 800C, ou seja, de $14,3 \%$, conduziu a um decréscimo na duraça da secagem de 270 para $240 \mathrm{~min}$ ou, de outra forma, de $11,1 \%$, quando as sementes foram secadas entre teores de água de $16,0 \%$ e 13,0\%. Estes resultados estao em consonância com os obtidos por LASSERAN (1978), ao secar sementes de milho em secador de fluxo continuo.

$$
\text { Comparando-se, as velocidades de secagem, }
$$
nas três temperaturas do ar empregadas, observa-se que a 80 e 900C, seus valores foram, respectivamente, 27 e $52 \%$ maio- 
res do que a temperatura de $700 \mathrm{C}$, embora os aumentos correspondentes de temperaturas do ar tenham sido de 14,3 e $28,6 \%$

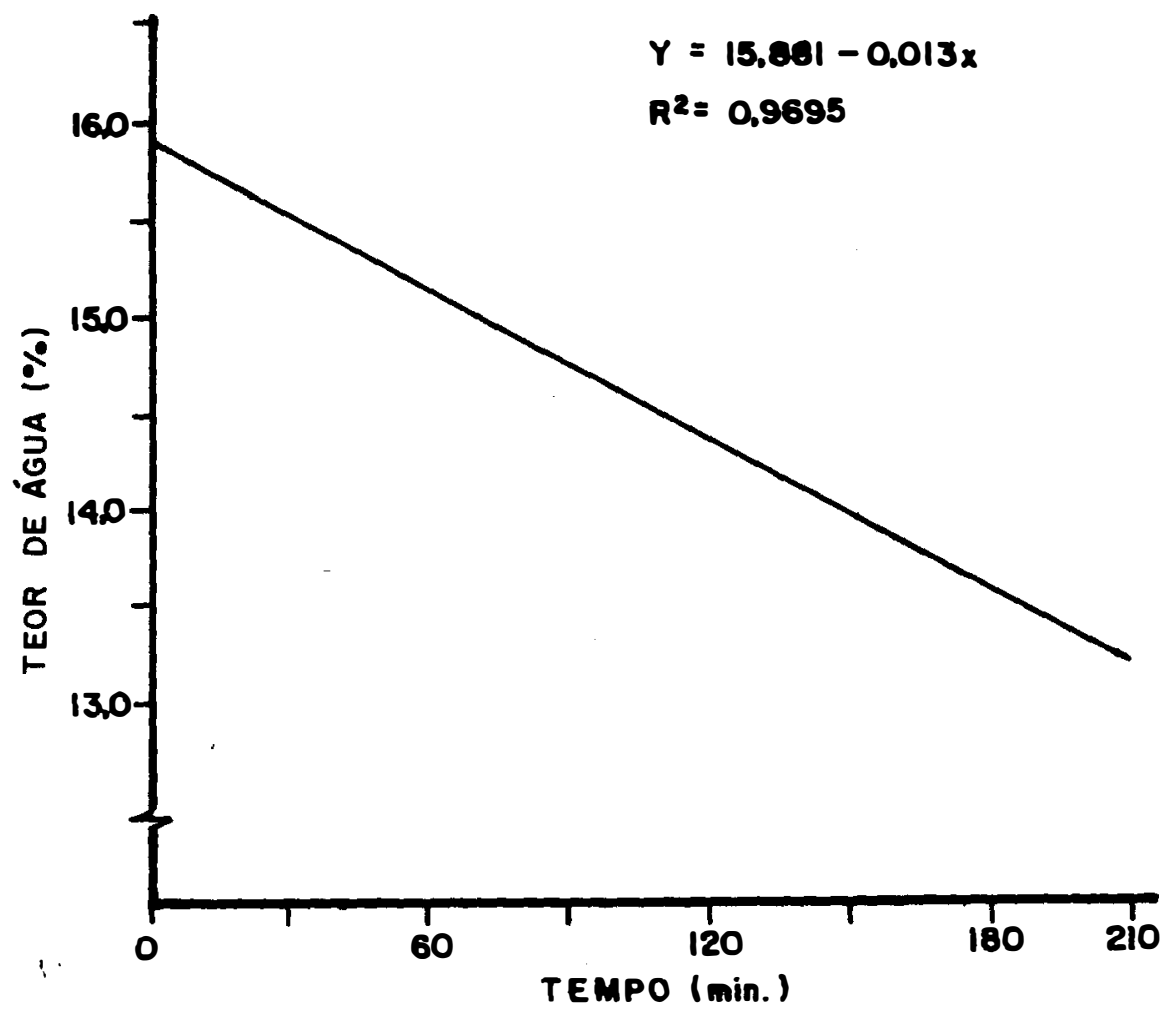

Figura 4 - Curva de secagem representando o comportamento do teor de água das sementes de milho em funça do tempo. Secagem intermitente à temperatura do ar de 900 C (Estudo 3 ).

o tempo necessário para a massa de sementes realizar uma passagem completa no sistema secador-elevador, foi de 90 min e à temperatura do ar de 9000, a duraçă da secagem foi de $210 \mathrm{min.} \mathrm{Levando} \mathrm{em} \mathrm{consideraçăo} \mathrm{a} \mathrm{relaçăo}$ de intermitência de 1:1,6, é possivel verificar que as 
sementes estiveram expostas ao ar aquecido durante 82 min e passaram cerca de 2,3 vezes pẹlo sistema de secagem.

Sob a temperatura do ar de $80^{\circ} \mathrm{C}$, o tempo de secagem foi de 240 mine as sementes passaram aproximadamente 2,7 vezes pelo sistema, permanecendo 94 min na câmara de secagem. Entretanto, a temperatura de 700C, o tempo de secagem foi de $300 \mathrm{~min}$, ou seja, 25 e $43 \%$ maior, do que a 80 e 90॰ $\mathrm{C}$, respectivamente $e$ as sementes deram 3,3 passagens no sistema secador-elevador, ficando 117 min expostas-ao ar aquecido.

Nas três temperaturas empregadas, a reduçăo do teor de água em funçăo do tempo foi constante, possivelmente porque a velocidade de deslocamento interno da água para a superficie da semente tenha sido igual ou superior a velocidade de remoça do vapor d'água pelo ar, conforme HALL (1980), FOUST et alii (1982) e LUZ (1986). Outra hipótese, provável, é a de que, embora a velocidade de transporte interno tenha sido menor do que a velocidade de evaporaçăo, ocorreu igualmente, durante o periodo de repouso, transferência de água do interior para a periferia da semente, aumentando a disponibilidade de água superficial a ser evaporada.

A velocidade de secagem depende da temperatura, umidade relativa e fluxo do ar, do tempo de exposiçao a estas condiçôes, dos teores de água inicial e final (HUKILL, 1972; LASSERAN, 1978), de caracteristicas da semente 
e das propriedades da interface semente-ar (SODHA et alii, 1987). Os teores de agua inicial e final da semente, a umidade relativa e o fluxo do ar, assim como o tempo de exposiço ao ar aquecido em cada passagem pelo sistema secador-elevador, nao apresentaram diferencas marcantes nas três secagens, empregando o método intermitente. Entretanto, a temperatura do ar e, em consequência, a temperatura da massa de sementes foram consideravelmente diferentes, de tal forma que quanto mais elevada a temperatura, maior foi a velocidade de secagem e menor o tempo total de exposiço ao ar aquecido.

As velocidades de secagem de $0,52,0,66$ e $0,79 \% / h$, obtidas no presente trabalho, evidenciam que as sementes de milho apresentam secagem lenta concordando com a afirmaçao de KREYGER (1973), comparativamente às sementes de arroz, que alcançam 1,6 a $2,0 \% / h$, ao utilizar no método intermitente, temperaturas do ar de 700C (LUZ, 1986) e às sementes de azevém anual (Lolium multiflorum L.) que podem chegar a 2,0\%/h, empregando ar à 800 C (BOUNOUS, 1986).

A relaçao entre o teor de água da semente e - tempo de secagem foi representada por funçøes lineares nas três temperaturas empregadas. Esta ocorrência vem ao encontro dos resultados alcançados por LUZ (1986), BOUNOUS (1986) e VEGA (1989) ao utilizarem, também, o método intermitente. Este comportamento, entretanto, contraria as afirmaç8̧es de KREYGER (1973), BROOKER et alii (1974), HALL 
(1980), FOUST et alii (1982) e SODHA et alii (1987). Segundo estes autores, as sementes apresentam periodo de secagem, a velocidade constante, muito curto ou inexistente, sendo a curva caracteristica de secagem, representada por uma combinaçao de segmentos, retilineos e curvilineos.

Contudo, algumas consideraçôes devem ser feitas, visando auxiliar a compreensao da discordancia anteriormente mencionada:

\section{- a curva caracteristica de secagem,} descrita pelos autores, foi obtida, experimentalmente, na secagem estacionária e continua de um produta, em camada de pequena espessura, sob condiçaes constantes de temperatura, umidade relativa e velocidade do ar;

- as curvas de secagem, obtidas mo presente trabalino, têm validade para teores de água entre 16,5 e $13,0 \%$, representando um segmento intermediário da curva caracteristica, nå expressando o comportamento da reduçă da água da semente em funçăo do tempo, para teores além de $16,5 \%$ e aquém de $13,0 \%$;

- a taxa de remoçao do vapor dágua pelo ar, nå foi, provavelmente, afetada, de forma acentuada, por limitaçâs na taxa de transporte interno de água, devido a intermitência; dessa forma, o teor de água decresceu à velocidade constante, dentro do intervalo estudado. 
Levando em conta que uma secagem rápida aumenta a possibilidade de fissuras internas e superficiais na semente, causadas pela retraço das camadas externas năo acompantiada pelas internas, conforme TOLEDO \& MARCOS FILHO (1977) e CARVALHO \& NAKAGAWA (1988), para as sementes de milho, que apresentam baixa velocidade de secagem, o método intermitente pode se constituir numa alternativa viável, uma vez que, durante o periodo de repouso, ocorre uma reduçăo nos gradientes de umidade e temperatura, minimizando os possiveis danos térmicos.

\subsection{Efeitos sobre a qualidade das sementes}

\subsubsection{Estudo 1}

Na Tabela 8, sao apresentados os resultados da análise de variância (Teste F), dos dados referentes as determinaçaes para a avaliaça da qualidade das sementes, revelando diferenças signficativas para a interacăo tratamentos de secagem versus épocas, na determinaçăo do teor de água e na incidência de Penicillium spp. Nos testes de germinaça, envelhecimento rápido, emergência em campo e no exame de sementes infestadas e na incidência de Fusarium moniliforme e Cephalosporium spp. foram significativos, apenas, os efeitos das épocas. 
Tabela 8. Estudo 1- Resultados da análise de variância (Teste $F$ ) dos dados referêntes as determinaçdes para a avaliação da qualidade de sementes de milho.

Determinaçoes

Causas de variaçăo

Tratamentos

Épocas ( $E$ )

$T \times E$

de secagem( T)

TCT I .

NS

ESDMV=

NS

DT I $=$

NS

Teor de água

NS

$* *$

$* *$

Germinaรă

NS

**

NS

Envelhecimento rápido

NS

$* *$

NS

Frio sem solo

NS

NS

NS

Emergência em campo

NS

**

NS

Sementes infestadas

NS

$* *$

NS

Penicillium spp.

$* *$

$* *$

Aspergillus SpP.

NS

NS

NS

Fusarium moniliforme

NS

$* *$

NS

Cephalosporium spp.

NS

$* *$

NS

2TCTI = Teste de coloraça de tintura de iodo
IESDMV = Exame de sementes com dano mecānico visivel
־DTI = Determinaça do total de impurezas
NS Indica ausência de significancia
* Indica significancia ao nivel de probabilidade de $5 \%$
** Indica significancia ao nivel de probabilidade de $1 \%$.

Com relaçăo aos danos mecânicos, avaliados pelo teste de coloraçăo de tintura de iodo, verificou-se 
que as sementes, submetidas aos três tratamentos de secagem, apresentaram resultados considerados elevados (Tabela 9).

Nas três déterminaçôs empregadas na avaliaça dos danos mecânicos em sementes, nAo foram observadas diferencas entre os tratamentos de secagem (Tabela 9) e os resultados foram similares áos obtidos na determinaça da qualidade inicial (Tabela 4).

Tabela 9. Estudo 1 - Comparacăo de médias dos dados do teste de coloracăo de tintura de iodo (TCTI), exame de sementes com dano mecânico visivel (ESDMV) e determinaça do total de impurezas (DTI)para os efeitos de tratamentos de secagem.

Tratamentos

Determinaçôes

de secagem

TCTI $(\%)$

DTI $(\%)$

\begin{tabular}{|c|c|c|c|}
\hline SN & $20,6 a$ & $7,2 a$ & 2,1 a \\
\hline SAN & $22, \mathrm{Oa}$ & $6,5 a$ & $1,8 a$ \\
\hline$S A$ & $21,2 a$ & $6,3 a$ & $1,8 a$ \\
\hline
\end{tabular}

Medias

21,3

6,7

1,9

CV $(\%)$

9,23

18,16

7,52

Médias seguidas pela mesma letra minúscula na mesma coluna, nă diferem entre si pelo teste de Tukey, ao nivel de $5 \%$ de probabilidade.

A Tabela 10 apresenta a comparaça de médias dos dados de teor de agua das sementes, onde é possivel verificar que os tratamentos SN, SAN e SA nao diferiram 
entre si, nas épocas $E_{2}, E_{2}$ e $E_{4}$. Na época $E_{.3}$, os teores de áqua das sementes nos tratamẹtos SN e SAN nao diferiram entre si; entretanto, foram inferiores ao do tratamento SA. As sementes, submetidas aos tratamentos SN e SAN, sofreram um acréscimo no teor de água, da primeira para a segunda época, voltando, na terceira e quarta épocas, aos teores iniciais, nåo obstante, a variaçao máxima tenha sido de $1 \%$. No tratamento SA, o teor de água inicialmente aumentou de $11,6 \%$, na época $E_{2}$, para $12,3 \%$, na época $E_{2}$; a seguir, reduziu de $12,1 \%$, na época $E_{3}$, para $11,3 \%$, na época $E_{4}$, de tal forma que a maior diferença também alcançou $1 \%$, entre as épocas $E_{2}$ e $E_{4}$.

As sementes, apesar de acondicionadas em embalagens que permitem trocas de vapor d'água com o ar exterior (sacos de papel multifolhado), nao apresentaram variaçôs apreciáveis no seu teor de água em funça das flutuaçöes experimentadas pela umidade relativa e pela temperatura do ambiente, durante o periodo de armazenamento (Figura 5). Todavia, observa-se que o incremento do teor de água, verificado entre as épocas $E_{1}$ e $E_{2}$, coincidiu com o periodo em que ocorreram variaçoes crescentes da umidade relativa do ar e decrescentes da temperatura ambiental cujo efeito, sobre o teor de água das sementes, é considerado normal pela literatura (NELLIST \& HUGHES, 1973 ; DELOUCHE \& POTTS, 1974; POPINIGIS, 1976; PUZZI, 1986; SILVA, 1986; CARVALHO \& NAKAGAWA, 1988). 
Tabela 10. Estudo 1. - Comparaçăo de médias dos dados de teor de agua, germinaçăo, envelhecimento rápido e frio sem solo,nas épocas $E_{1}, E_{9}, E_{3}$, e $E_{4}$, para os efeitos de tratamentos de secagem.

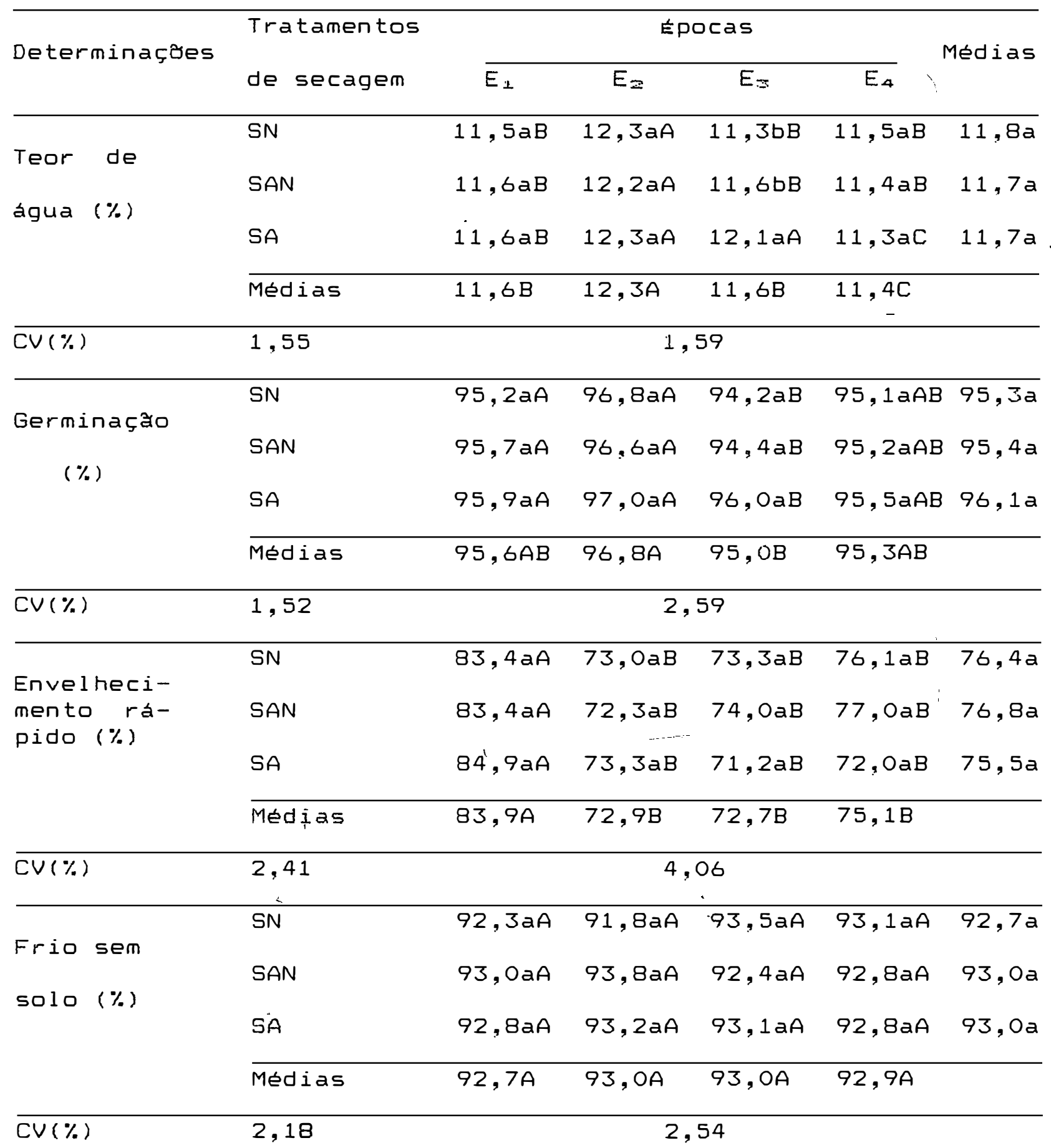

Médias seguidas pela mesma letra minúscula na mesma coluna e mesma letra maiúscula na mesma linha, nåo diferem entre si pelo teste de Tukey, ao nivel de 5\% de probabilidade. 


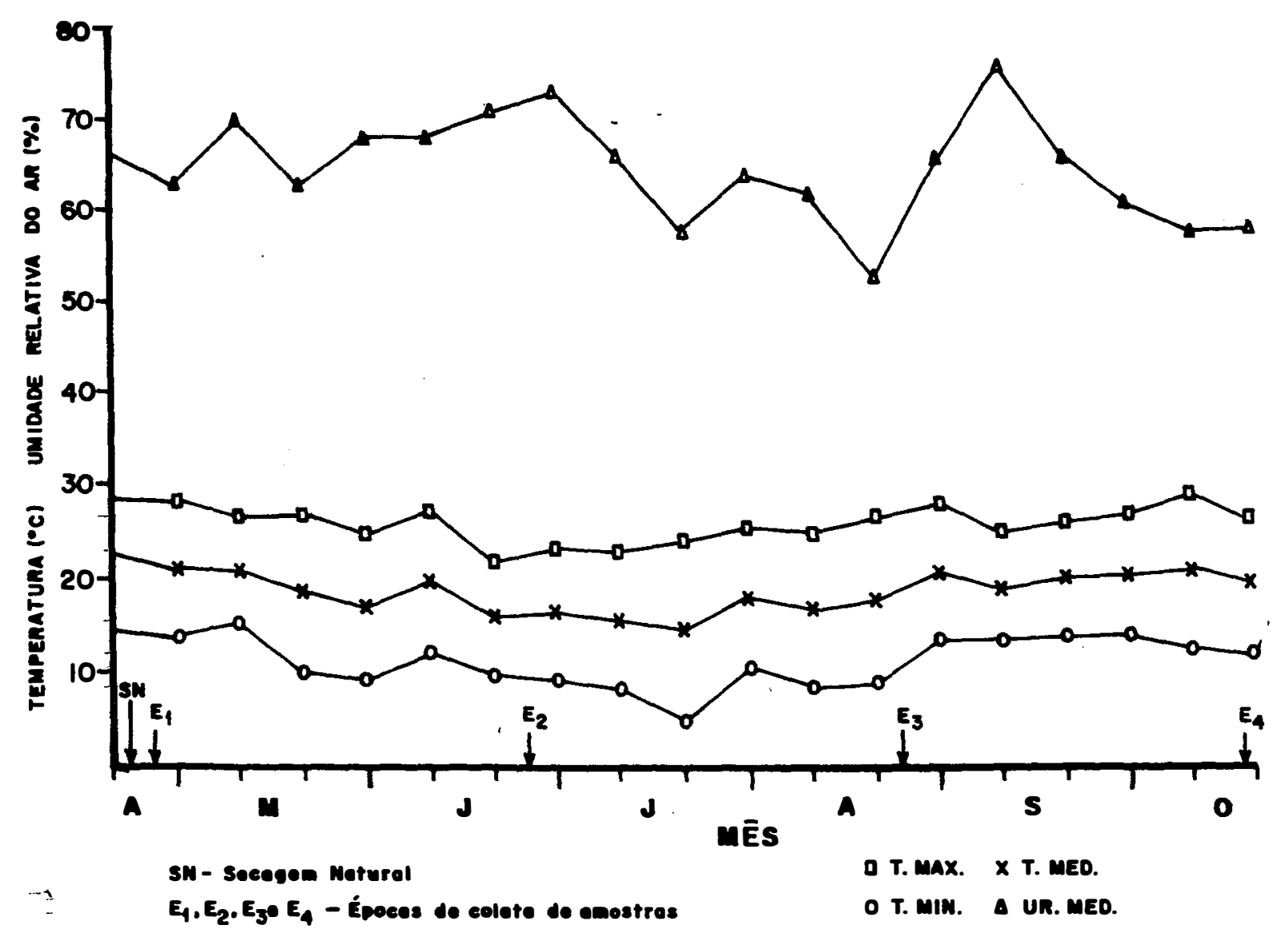

Figura 5. Temperaturas máximas, médias e minimas (oC) e umidades relativas do ar medias $(\%)$, por decêndios, registradas no periodo de 20/04/89 a 21/10/89, em Piracicaba, SP.

As comparaçôs de médias dos dados de germinaçăo, envelhecimento rápido e frio sem solo (Tabela 10), nåo mostraram diferenças significativas entre os tratamentos de secagem, nas quatro épocas de avaliaçao. Pode ser verificado, entretanto, que no decorrer do periodo de armazenamento, houve reduçao na porcentagem de germinaça, na época $E 3.0$ vigor das sementes avaliado pelo teste de envelhecimento rápido foi superior na primeira em relaçao as demais epocas, variando de $83,9 \%$ para $75,1 \%$, entre a primeira e a quarta epocas. 
A Tabela 11 fornece as comparaçöes de médias dos dados de emergência em campo e de sementes infestadas, para os efeitos de tratamentos de secagem, nas epocas $E_{2} e$ E4, onde é possivel observar que os tratamentos de secagem nåo diferiram entre si, nas duas epocas de analise.

Tabela 11. Estudo 1. - Comparacăo de médias dos dados de emergência em campo e de sementes infestadas, épocas $E_{3}$ e $E_{4}$. para os efeitos de tratamentos de secagem.

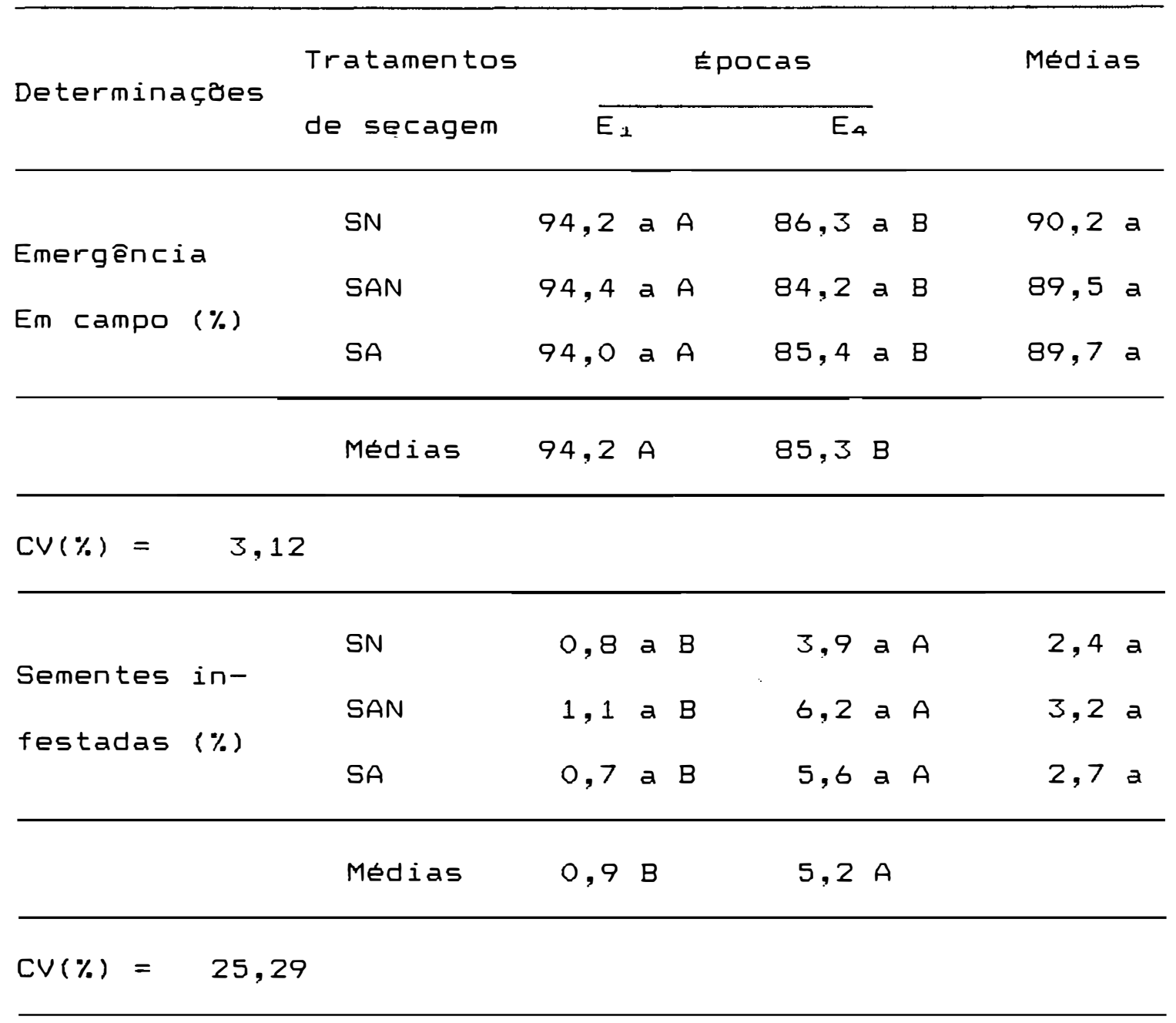

Médias seguidas pela mesma letra minúscula na mesma coluna e mesma letra maiúscula na mesma linha, nåo diferem entre si pelo teste de Tukey, ao nivel de 5\% de probabilidade. 
A média da porcentagem de emergência em campo decresceu de $94,2 \%$, na época $E_{2}$, para $85,3 \%$, na época $E_{4}$, enquanto o nivel de infestaça por insetos aumentou de 0,9\% para 5,2\%. Cabe lembrar que as sementes foram submetidas ao expurgo, aos 120 dias de armazenamento, empregando-se a dosagem recomendada, conforme BITRAN (1989).

As comparaçôes de médias de incidência de Penicillium spp., Aspergillus spp., Fusarium moniliforme e Cephalosporium spp., para os efeitos de tratamentos de secagem, nas épocas $E_{1}$ e $E_{4}$, saro mostradas na Tabela 12.

Quanto ao fungo Penicillium spp., é possivel verificar maior incidencia nas sementes submetidas ao tratamento SAN em relaçao aos tratamentos SN e SA,na primeira época. Por outro lado, na quarta época, as sementes do tratamento SA apresentaram menor incidencia deste fungo em relaçao aos tratamentos SN e SAN, sendo que neste periodo, sua porcentagem de ocorrência aumentou, apenas, no tratamento SN. A menor incidência deste patógeno, nas sementes secadas artificialmente a temperatura do ar de $70 \circ C$, pode ser resultante da aça do ar aquecido que, talvez, tenta propiciado um tratamento fisico (termoterapia) as sementes, embora existam indicaçôes da baixa eficiência do método, conforme relatos de LASCA(1986) e SOAVE \& MORAES (1987).

Com relaçao à incidência de Aspergillus 
Tabela 12. Estudo 1. - Comparaçăo de médias de incidência de Penicillium spp., Aspergillus spp., Fusarium moniliforme e Cephalosporium spp.,nas épocas $E_{i}$ e $E_{4}$, para os efeitos de tratamentos de secagem.

\begin{tabular}{|c|c|c|c|c|}
\hline \multirow{2}{*}{ Determinaçoes } & \multirow{2}{*}{$\begin{array}{l}\text { Tratamentos } \\
\text { de secagem }\end{array}$} & \multicolumn{2}{|c|}{ Epocas } & \multirow{2}{*}{ Medias } \\
\hline & & $\overline{E_{1}}$ & $\overline{E_{4}}$ & \\
\hline \multirow{2}{*}{ Penicillium } & SN & $80,3 \circ B$ & $97,3 a A$ & $88,7 a$ \\
\hline & SAN & $92,2 a A$ & $95,8 a A$ & $94,1 a$ \\
\hline \multirow{2}{*}{ spp. $(\%)$} & $S A$ & $75,1 \mathrm{bA}$ & $76,5 b A$ & 75,86 \\
\hline & Medias & $82,4 B$ & $90,7 A$ & \\
\hline \multicolumn{5}{|l|}{$\overline{C V(\%)}=7,97$} \\
\hline \multirow{2}{*}{ Aspergillus } & SN & $11,9 a A$ & $13,6 a A$ & $12,7 a$ \\
\hline & SAN & $14,0 a A$ & $11,9 a A$ & $12,8 a$ \\
\hline \multirow{2}{*}{ Spp. $(\%)$} & $S A$ & $14,9 a A$ & $15,8 a A$ & $15,6 a$ \\
\hline & Médias & $13,6 A$ & $14,2 A$ & \\
\hline \multicolumn{5}{|l|}{$\overline{C V}(\%)=15,07$} \\
\hline \multirow{4}{*}{$\begin{array}{l}\text { Fusarium } \\
\text { moniliforme } \\
(\%)\end{array}$} & SN & $8,2 a B$ & $45,0 a A$ & $24,1 a$ \\
\hline & SAN & $8,4 a B$ & $42,9 a A$ & $23.7 a$ \\
\hline & $S A$ & $14,3 a B$ & $45,8 a A$ & $28,7 a$ \\
\hline & Médias & $10,3 \mathrm{~B}$ & $46,6 A$ & \\
\hline \multicolumn{5}{|l|}{$\overline{C V}(\%)=16,75$} \\
\hline \multirow{2}{*}{ Cephalospo- } & SN & $40,5 a A$ & $8,4 a B$ & $22,3 a$ \\
\hline & SAN & $53, O a A$ & $6,1 \mathrm{aB}$ & $25,8 a$ \\
\hline \multirow[t]{3}{*}{ rium spp. (\%) } & & & & \\
\hline & $S A$ & $50,5 a A$ & $8,3 a B$ & $26,5 a$ \\
\hline & Médias & $48, O A$ & $7,6 \mathrm{~B}$ & \\
\hline
\end{tabular}

$\overline{C V}(\%)=12,72$

Médias seguidas pela mesma letra minúscula na mesma coluna e mesma letra maiúscula na mesma linha, năo diferem entre si pelo teste de Tukey, ao nivel de 5\% de probabilidade. 
spp., Fusarium moniliforme e Cephalosporium spp, nao houve efeito dos tratamentos de secagem. Entretanto, entre o inicio e o final do periodo de armazenamento, a recuperaçao de Fusarium moniliforme aumentou de $10,3 \%$ para $44,6 \%$, enquanto a de Cephalosporium 5pp, diminuiu de 48,0\% para 7,6\%. Cabe destacar que, o fungo Fusarium moniliforme, apresenta grande significado na cultura do milho, podendo causar o apodrecimento de sementes e a morte de plântulas e, em final de ciclo, provocar a podridao do colmo e da espiga (LUCCA FILHO, 1987 e MENEZES, 1988).

A menor incidencia de Fusarium moniliforme, detectada na primeira epoca, pode ser atribuida a presença de Cephalosporium spp., causando efeitos inibitórios e/ou competitivos nas sementes e mascarando, consequentemente, os resultados. Na epoca $E_{4}$, nao obstante a deteç̧o de Fusarium moniliforme, em 44,6\% das sementes, nå se observaram reduçøes marcantes na germinaçăo, concordando com MENEZES (1988), que afirma apresentar, o referido fungo, tipos saprofitas com mesma morfologia, que podem estar presentes em sementes de milho germinadas e nåo germinadas.

Durante o periodo de armazenamento, a umidade relativa do ar variou entre $60 \%$ e $70 \%$ e a temperatura ambiental média manteve-se abaixo de $20^{\circ} \mathrm{C}$ (Figura 5); estas condiçoes podem ser consideradas adequadas para a preservaça da qualidade fisiologica de sementes de milho 
com teores de água entre 11,3 e $12,3 \%$ (Tabela 9), por o a 9 meses, em regioes tropicais e subtropicais, conforme DELOUCHE et alii (1973) e DELOUCHE \& POTTS (1974).

Embora as condiçoes ambientais de armazenamento tenham sido, a priori, adequadas, verificou-se que 0 vigor das sementes, avaliado pelo teste de envelhecimento rápido (Tabela 10) e pela emergência em campo (Tabela 11) teve tendencia decrescente no decorrer do periodo de armazenamento. Este fato, aparentemente normal, pode ter sido agravado pelos efeitos das danificaçoes mecânicas, ocorridas na colheita. As sementes, embora tenham sido colhidas na faixa de teor de água em que a intensidade de danos mecânicos seria minima, conforme JUSTICE \& BASS (1979) e CARVALHO \& NAKAGAWA (1988), apresentaram-se severamente danificadas em razao, possivelmente, da inadequada regulagem da máquina de colheita.

Estas reduçaes, ocorridas na qualidade fisiologica das sementes, podem, tambem, ser atribuidas a açăo de insetos, cujo nivel de infestaçao aumentou de forma considerável durante o armazenamento, concordando com as informaçöes de HOWE (1975), POPINIGIS (1975), POPINIGIS (1985) E CARVALHO \& NAKAGAWA (1988).

Em linhas gerais, os resultados do Estudo 1 , permitem constatar que os tratamentos de secagem nao influenciam a qualidade fisioldgica das sementes. Por outro 
lado, a secagem artificial (secagem intermitente) pode determinar uma reduçao na incidẹncia de Penicillium spp.

\subsubsection{Estudo 2}

Os resultados da análise de variancia (Teste de F) dos dados referentes as determinaçoes para a avaliaçao da qualidade das sementes, encontram-se na Tabela 13, mostrando diferenças significativas, para a interaçăo tratamentos de secagem versus épocas, na determinaçăo do teor de água e na incidência de Penicillium spp. e Cephalasporium spp. Os efeitos dos tratamentos de secagem foram significativos nos testes de coloraçă de tintura de iodo, envelhecimento rápido e emergência em campo. Ds efeitos das épocas foram significativos nos testes de envelhecimento rápido e emergência em campo e na incidencia de Aspergillus spp. e Fusarium moniliforme.

Os danos mecânicos em sementes, avaliados pelo teste de coloraçăo de tintura de iodo (Tabela 14), apresentaram maior porcentagem no tratamento SA em relaçăo ao SAN, apesar de SA nao diferir de SN. Com relaçăo ao dano mecânico visivel e ao total de impurezas, os resultados mostraram similitude entre os tratamentos e à determinaçao da qualidade inicial (Tabela 4). 
Tabela 13. Estudo 2, Resultados da análises de variancia (Teste F) dos dados referentes as determinaçöes para a avaliaçăo da qualidade de sementes de milho.

Determinaçסిes

Causas de variação

Tratamentos
de secagem (T)

TCT I ${ }^{2}$

*

ESDMV $=$

NS

DT I $=$

NS

Teor de água

NS

**

*

Germinaçăo

NS

NS

NS

Envelhecimento rápido

*

**

NS

Frio sem solo

NS

NS

NS

Emergência em campo

**

**

NS

Sementes infestadas

NS

NS

NS

Penicillium spp.

$* *$

NS

Aspergillus spp.

NS

*

NS

Fusarium moniliforme

NS

$* *$

NS

Cephalosporium spp.

NS

¿TCTI = Teste de coloraçăo de tintura de iodo

IESDMV = Exame de sementes com dano mecânico visivel

"xDT = Determinaça do total de impurezas

NS Indica ausência de significância

* Indica significância ao nivel de probabilidade de $5 \%$

* Indica significância ao nivel de probabilidade de $1 \%$. 
Tabela 14. Estudo 2. - Comparaçao de médias dos dados do teste de coloraça de tintura de iodo (TCTI), exame de sementes com dano mecânico visivel (ESDMV) e determinaça do total de impurezas (DTI), para os efeitos de tratamentos de secagem.

Tratamentos

Determinaçơes

de secagem

TCT I $(\%)$

$\operatorname{ESDMV}(\%)$

DT I $(\%)$

SN

16,4 ab

$7,6 \quad a$

2,2 a

SAN

$15,1 \quad b$

6,8 a

$2,0 \quad a$

SA

17,4 a

6,3 a

2,1 a

Médias

16,3

6,9

2,1

CV $(\%)$

5,01

18,83

8,74

Médias seguidas pela mesma letra minúscula na mesma coluna, nao diferem entre $5 i$ pelo teste de Tukey, ao nivel de $5 \%$ de probabilidade.

$\mathrm{Na}$ Tabela 15 så apresentadas as comparaçôes de médias para os efeitos de tratamentos de secagem, na determinaçao do teor de água e nos testes de germinaçăo, envelhecimento rápido e frio sem solo, durante as quatro épocas de avaliaçăo.

0 teor de água das sementes, submetidas à secagem natural, aumentou $0,5 \%$ nos primeiros dois meses de armazenamento e, a partir dai, apresentou um decréscimo de $1,6 \%$, até o final de seis meses, variando de $12,2 \%$ na época $E_{2}$, para $10,6 \%$, na época $E_{4}$. As sementes que sofreram as secagens artificial-natural (SAN) e artificial (SA) apre- 
sentaram tendências semelhantes, havendo reduçao no teor de água a partir de 120 dias de armazenamento. No final do periodo de armazenamento, as sementes submetidas aos três tratamentos de secagem, atingiram os mais baixos teores de água, coincidindo com os decêndios em que a umidade relativa estava em franco declinio e a temperatura do ar média em gradual elevaçă, conforme pode ser observado na Figura 5 .

Com relaçå à germinaçăo e ao vigor, avaliado pelo teste de frio sem solo, pode ser verificado que as sementes dos três tratamentos de secagem apresentaram resultados similares durante o periodo de seis meses de armazenamento.

o vigor das sementes, avaliado pelo teste de envelhecimento rápido, no tratamento SA foi superior ao tratamento SN, nas quatro épocas, enquanto os tratamentos SA e SAN חăo diferiram entre si. Por outro lado, é possivel detectar reduçoses de vigor, nos três tratamentos, a partir de 120 dias de armazenamento.

As comparaçaes de médias de emergência em campo indicaram similaridade entre os tratamentos SN e SAN, nas duas épocas de avaliaçao, embora tenham apresentado um desempenho inferior ao tratamento SA (Tabela 16 ). Convém ressaltar, entretanto, que houve um efetivo declinio na porcentagem de emergência das plantas em campo, após 180 dias de armazenamento. 
Tabela 15. Estudo 2. - Comparaçao de médias dos dados de teor de água, germinaçăo, envelhecimento rápido e frio sem solo, nas epocas $E_{2}, E_{2}, E_{m}$, e $E_{4}$, para os efeitos de tratamentos de secagem.

\begin{tabular}{|c|c|c|c|c|c|c|}
\hline \multirow{2}{*}{ Determinaçơs } & \multirow{2}{*}{$\begin{array}{l}\text { Tratamentos } \\
\text { de secagem }\end{array}$} & \multicolumn{4}{|c|}{ Epocas } & \multirow{2}{*}{ Médias } \\
\hline & & $\overline{E_{1}}$ & $E_{2}$ & $E_{:=}$ & $\overline{E_{A}}$ & \\
\hline \multirow{4}{*}{$\begin{array}{l}\text { Teor de } \\
\text { água }(\%)\end{array}$} & SN & $11,7 a B$ & $12,2 a A$ & $11,7 b \mathrm{~B}$ & $10,60 \mathrm{C}$ & $11,5 a$ \\
\hline & SAN & $11,7 \mathrm{a} A$ & 12, OabA & $12, \mathrm{OaA}$ & $10.9 \mathrm{aB}$ & $11,6 a$ \\
\hline & $S A$ & $11,8 \mathrm{aA}$ & $11,8 \sqcup A$ & $11,8 a b A$ & $11,1 \mathrm{aB}$ & $11,6 a$ \\
\hline & Médias & $11,7 A$ & $12, O A$ & $11,8 \mathrm{~A}$ & $10,9 \mathrm{~B}$ & \\
\hline$\overline{C V}(\%)$ & 1,11 & \multicolumn{4}{|c|}{1,94} & \\
\hline \multirow{4}{*}{ Germinaçåo } & SN & $95,5 a A$ & $96,5 a A$ & $97,1 \mathrm{aA}$ & $95,2 a A$ & $96,1 a$ \\
\hline & SAN & $95,3 a A$ & $96,0 a A$ & $96,5 a A$ & $96,5 a A$ & 96.12 \\
\hline & $S A$ & $96,8 a A$ & $97,0 a A$ & $96,5 a A$ & $95,5 a A$ & $96,5 a$ \\
\hline & Médias & $95,9 A$ & $96,6 A$ & $96,7 A$ & $95,6 A$ & \\
\hline$\overline{C V}(\%)$ & 1,01 & \multicolumn{4}{|c|}{2,44} & \\
\hline \multirow{4}{*}{$\begin{array}{l}\text { Envel heci- } \\
\text { mento rá- } \\
\text { pido (\%) }\end{array}$} & SN & $84,5 b A$ & $86,2 b A$ & $83,4 \sqcup B$ & $82,66 B$ & \\
\hline & SAN & $86,3 a b A$ & $91,6 a A$ & $84,2 a b B$ & $83,8 a b B$ & $85,9 a b$ \\
\hline & SA & $90,7 a A$ & $91,3 a A$ & $86,0 a B$ & $85,9 a B$ & $88,9 a$ \\
\hline & Médias & $87,2 A$ & $90,1 \mathrm{~A}$ & $84,3 B$ & $84,1 \mathrm{~B}$ & \\
\hline$\overline{C V}(\%)$ & 2,64 & \multicolumn{4}{|c|}{5,02} & \\
\hline \multirow{4}{*}{$\begin{array}{l}\text { Frio sem } \\
\text { solo (\%) }\end{array}$} & SN & $92,4 a A$ & $95,0 a A$ & $94,0 a A$ & $94,6 a A$ & $94,0 a$ \\
\hline & SAN & 93,1 aA & $95,3 a A$ & $94,9 a A$ & $91,8 a A$ & $93,8 a$ \\
\hline & SA & $93,7 a A$ & $94,4 a A$ & 93,1 aA & $93,7 a A$ & $93,7 a$ \\
\hline & Médias & $93,1 A$ & $94,9 A$ & $94,0 A$ & $93,4 A$ & \\
\hline$\overline{C V}(\%)$ & 1,82 & & & & & \\
\hline
\end{tabular}

Médias seguidas pela mesma letra minúscula na mesma coluna e mesma letra maiúscula na mesma linha, nao diferem entre si pelo teste de Tukey, ao nivel de $5 \%$ de probabilidade. 
Tabela 16. Estuda 2 - Comparaçao de médias dos dados de emergência em campo e de sementes infestadas, nas épocas $E_{2}$ e $E_{4}$. para os efeitos de tratamentos de secagem.

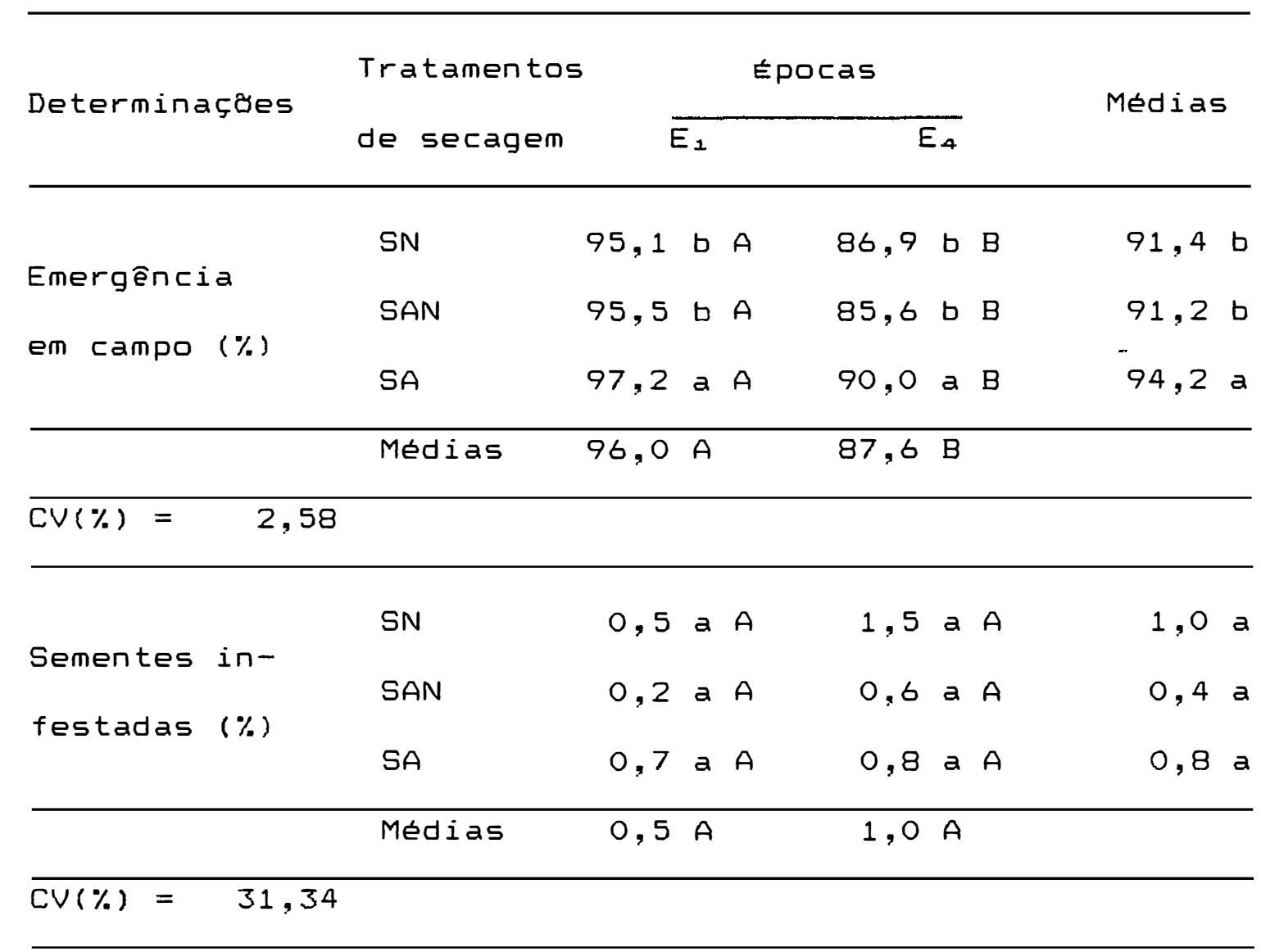

Médias seguidas pela mesma letra minúscula na mesma coluna e mesma letra maiúscula na mesma linha, nåo diferem entre si pelo teste de Tukey, ao nivel de 5\% de probabilidade.

Nas Tabelas 15 e 16 é possivel verificar que a indicaçăo constante do teste de envelhecimento rápido, de que o tratamento SA foi superior a SN, confirmou-se nas duas épocas ( $E_{2} \mathrm{e}_{4}$ ) no teste de emergência em campo, 
assim como um comportamento superior das sementes, dos três tratamentos de secagem, na epoca $E_{1}$ em relaça a $E_{4}$.

Os niveis de infestaçăo por insetos foram similares entre os tris tratamentos, nas duas épocas de análise (Tabela 16), variando de 0,2 a $1,5 \%$.

Na Tabela 17 så apresentadas as comparaçaes de médias de incidência de Penicillium spp." Aspergillus spp., Fusarium moniliforme e Cephalosporium spp., para os efeitos de tratamentos de secagem, nas duas épocas de ava1 iaçăo.

A incidência de Penicillium spp., foi menor nas sementes submetidas aos tratamentos SAN e SA em relaçao ao tratamento SN, nas duas épocas, sendo que as sementes que sofreram apenas secagem artificial, apresentaram uma diminuiçă de $9,8 \%$, na incidência deste fungo, no decorrer do periodo de armazenamento.

Em cada época de avaliaçăo, detectaram-se incidencias similares de Aspergillus spp., nos três tratamentos, havendo porém, uma menor deteç̧ăo média na época $E_{1}$ $(9,4 \%)$, em relaçao à época $E_{4}(15,1 \%)$. Este mesmo comportamento verificou-se em relaçao a Fusarium moniliforme, cuja recuperaça foi de $10,8 \%$, na primeira época e de $44,3 \%$, na quarta época. 
Tabela 17. Estudo 2 - Comparação de médias de incidência de Penicillium spp., Aspergillus spp., Fusarium moniliforme e Cephalosporium spp.,nas épocas $E_{2}$ e $E_{A}$, para os efeitos de tratamentos de secagem.

\begin{tabular}{|c|c|c|c|c|}
\hline \multirow{2}{*}{ Determinaçöes } & \multirow{2}{*}{$\begin{array}{l}\text { Tratamentos } \\
\text { de secagem }\end{array}$} & \multicolumn{2}{|c|}{ EPOCas } & \multirow{2}{*}{ Médias } \\
\hline & & $\overline{E_{1}}$ & $\overline{E_{4}}$ & \\
\hline \multirow{2}{*}{ Penicillium } & $\mathrm{SN}$ & $94,8 a A$ & $98,8 a A$ & $97,1 a$ \\
\hline & SAN & $79.8 b A$ & $74,1 \mathrm{bA}$ & $77,4 b$ \\
\hline \multirow{2}{*}{ SPP. $(\%)$} & $S A$ & $82,4 b A$ & $72,6 b B$ & $77,6 b$ \\
\hline & Medias & $86,1 A$ & $83,5 A$ & \\
\hline \multicolumn{5}{|l|}{$\overline{C V}(\%)=6,81$} \\
\hline \multirow{4}{*}{$\begin{array}{l}\text { Aspergillus } \\
\text { spp. }(\%)\end{array}$} & SN & $11,2 \mathrm{aB}$ & $16,5 a A$ & $13,7 a$ \\
\hline & SAN & 8,1 a $B$ & $16,4 a A$ & $11,9 a$ \\
\hline & $S A$ & $9, \mathrm{OaB}$ & $12,6 a A$ & $10,7 a$ \\
\hline & Médias & $9,4 B$ & $15,1 \mathrm{~A}$ & \\
\hline \multicolumn{5}{|l|}{$C V(\%)=20,14$} \\
\hline \multirow{4}{*}{$\begin{array}{l}\text { Fusarium } \\
\text { moniliforme } \\
(\%)\end{array}$} & SN & $12,5 a B$ & $41,7 a A$ & $25,7 a$ \\
\hline & SAN & $10,7 a B$ & $43,1 \mathrm{aA}$ & $26,9 a$ \\
\hline & $S A$ & $8,4 a B$ & $45,2 a A$ & $27,2 a$ \\
\hline & Médias & $10,8 \mathrm{~B}$ & $44,3 A$ & \\
\hline \multicolumn{5}{|l|}{$\mathrm{CV}(\%)=10,54$} \\
\hline \multirow{2}{*}{ Cephalospo- } & SN & $47,5 b A$ & $0,9 a B$ & $17,2 a$ \\
\hline & SAN & $64,9 a A$ & $0,3 a B$ & $22,5 a$ \\
\hline \multirow[t]{3}{*}{ rium SPP. (\%) } & & & & \\
\hline & $S A$ & $66,5 a A$ & $O, O a B$ & $21,1 a$ \\
\hline & Médias & $59,8 A$ & $0,3 \mathrm{~B}$ & \\
\hline
\end{tabular}

$\overline{C V}(\%)=18,33$

Médias seguidas pela mesma letra minúscula na mesma coluna e mesma letra maiúscula na mesma linha, nå diferem entre si pelo teste de Tukey, ao nivel de $5 \%$ de probabilidade. 
Por outro lado, com relaçăo a Cephalosporium spp. foi detectada uma menor incidência nas sementes do tratamento SN do que nas dos tratamentos SAN e SA, embora sua incidência tenha diminuido de forma acentuada, nos três tratamentos, ao longo do periodo de armazenamento. Esta última constataçåo está de acordo com os relatos de SOAVE \& MORAES (1987), WETZEL (1987) E MENTEN (1988) sobre os microrganismos de campo, cuja incidencia e/ou viabilidade tende a decrescer, após a colheita.

Embora a incidencia de Penicillium spp., nas duas épocas de avaliaçăo, tenha sido elevada, nåo se observaram reduçoes na viabilidade das sementes (Tabela 15), provavelmente, porque as condiçoes ambientais de armasenamento nåo foram favoraveis a elevaçăo da incidência deste patógeno, corroborando as afirmaçoes feitas por POPINIGIS (1985), WETZEL (1987) e MENTEN (1988).

Modificaçôes degenerativas, resultantes do avanço do processo de deterioraçăo das sementes, durante o armazenamento, detectadas pelo teste de envelhecimento rápido e de emergência em campo, podem ser atribuidas, dentre outros fatores, aos efeitos latentes dos danos mecânicos, causados as sementes, por ocasiao da colheita.

Fatores adversos, durante o desenvolvimento da semente e na fase de pré-colheita, também podem ter contribuido para uma deterioraça mais acelerada durante o armazenamento, conforme o relatado por HARRINGTON (1972), 
POPINIGIS (1976), JUSTICE \& BASS (1979), ROBERTS (1981), COPELAND \& MCDONALD (1985) e POPINIGIS (1985).

As informaçôes obtidas no Estudo 2, de uma maneira abrangente, permitem verificar que, a qualidade fisiológica das sementes năo difere entre os métodos de secagem estudados, nå obstante, as sementes secadas artificalmente tenham apresentado maior desempenho nos testes de envelhecimento rápido e emergência em campo. Por sua vez, a incidência de Penicillium spp. é menor nas sementes submetidas às secagens artificial-natural e artificial em relaçăo à secagem natural.

\subsubsection{Estudo 3}

Os resultados da análise de variância (Teste F) dos dados referentes às determinaçôes para avaliaçăo da qualidade das sementes săo apresentadas na Tabela 18, revelando diferenças significativas para a interaça tratamentos de secagem versus épocas, nos testes de germinação e envelhecimento rápido e na incidência de Penicillium spp. e Cephalosporium spp.. Foram significativos os efeitos dos tratamentos de secagem, na determinaçăo do teor de água e os efeitos das épocas, na determinaçăo do teor de água, no teste de emergência em campo, no exame de sementes infestadas e na incidência de Aspergillus spp. e Fusarium moniliforme. 
Tabela 18. Estudo 3. - Resultado da análise de variância (teste $F$ ) dos dados referentes as determiçôes para a avaliaçă da qualidade de sementes de milho.

Causas de variaçăo

Determinaçoes

$\begin{aligned} & \text { Tratamentos } \\ & \text { de secagem(T) Epocas }\end{aligned} \quad T \times E$

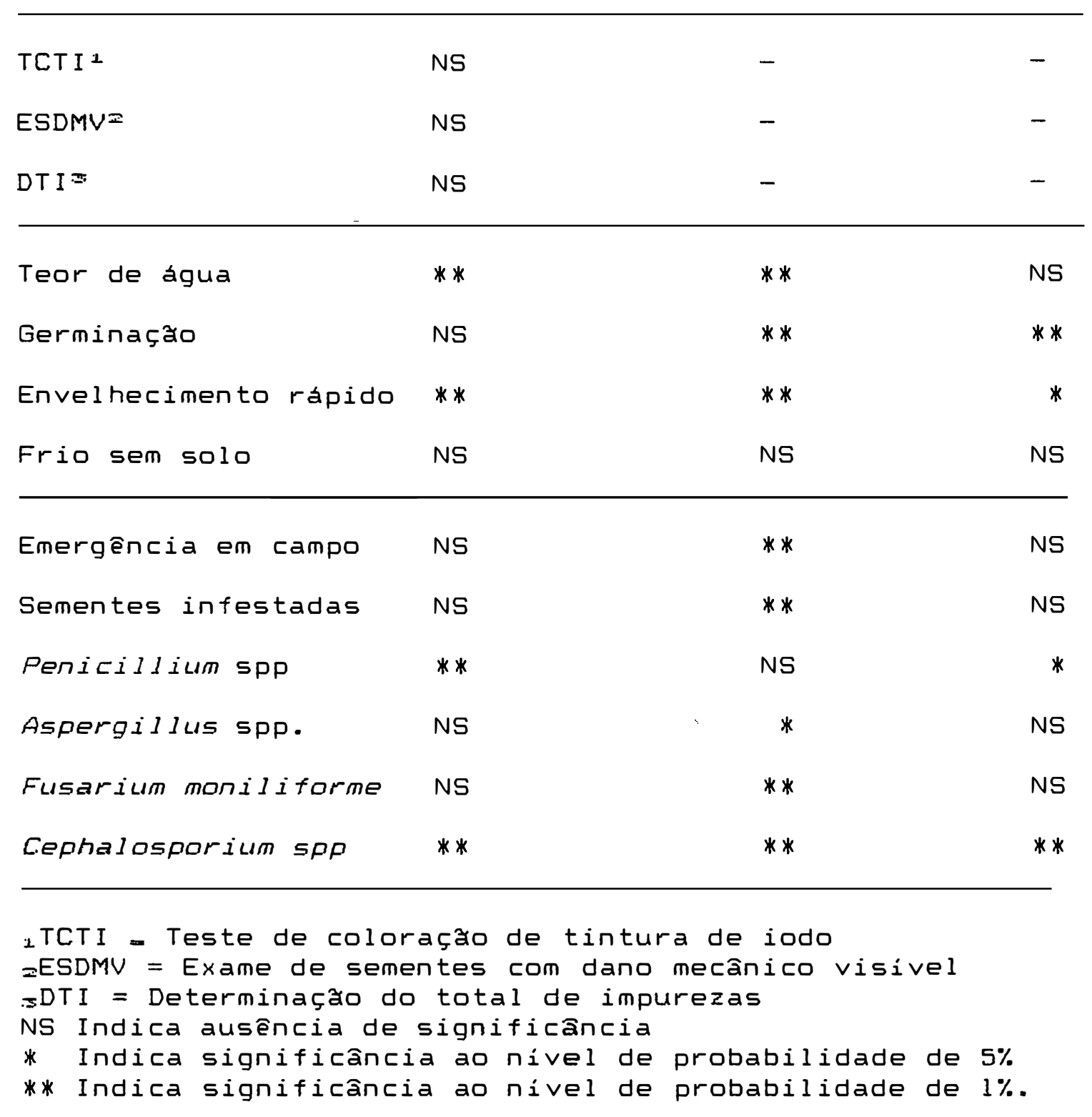


A proporçao de sementes mecanicamente danificadas, avaliada pelo teste de coloraçă de tintura de iodo, apresentou resultados semelhantes nos três tratamentos de Eecagem, variando entre 15,4\% no tratamento SAN e 18,5\%, no tratamento SA (Tabela 19). Comportamento similar entre os tratamentos foi verificado no exame de sementes com dano visivel, nao obstante a variaçao tenha sido de $6,3 \%$ no tratamento $5 A$ a $7,2 \%$ no tratamento SN.

Tabela 19. Estudo 3 -Comparaçăo de médias do teste de coloraçăo de tintura de iodo (TCTI), exame de sementes com dano mecânico visivel (ESDMV) e determinaçă do total de impurezas (DTI), para os efeitos de tratamentos de secagem.

\begin{tabular}{lccr}
\hline \multirow{2}{*}{$\begin{array}{l}\text { Tratamentos } \\
\text { de secagem }\end{array}$} & \multicolumn{3}{c}{ Determinaç8̈es } \\
\cline { 2 - 4 } & TCTI(\%) & ESDMV(\%) & DT I (\%) \\
\hline SN & $17,0 a$ & $7,2 a$ & $2,0 a$ \\
SAN & $15,4 a$ & $6,5 a$ & $1,8 a$ \\
SA & $18,5 a$ & $6,3 a$ & $1,8 a$ \\
\hline \multirow{2}{*}{ Médias } & 17,0 & 6,7 & 1,9 \\
\hline CV $(\%)$ & 7,82 & 15,76 & 10,68 \\
\hline
\end{tabular}

Médias seguidas pela mesma letra minúscula na mesma coluna, năo diferem entre si pelo teste de Tukey, ao nivel de $5 \%$ de probabilidade.

As comparaçôes de médias, para os efeitos de tratamentos de secagem, na determinaça do teor de água e 
nos testes de germinaçăo, envelhecimento rápido e frio sem solo, realizados nas quatro epocas de avaliaçăo, săo mostradas na Tabela 20.

Em cada época de avaliaçăo, os teores de água das sementes dos tratamentos SN e SAN apresentaram o mesmo comportamento, embora estatisticamente inferiores aos alcançados no tratamento SA. No decorrer do periodo de armazenamento, as sementes experimentaram variaçöes no teor de água, influenciadas pelas condiçôs ambientais de temperatura e umidade relativa do ar (Figura 5). Inicialmente, o teor de água médio aumentou de $11,6 \%$ (época $E_{2}$ ) para $12,6 \%$ (época $E_{z}$ ) e, a seguir, declinou de forma lenta, atingindo $11,7 \%$, aos 180 dias.

- maior teor de água, alcançado pelas sementes que sofreram, unicamente, secagem artificial á temperatura do ar de 900C, talvez, possa ser atribuido a menor integridade fisica do pericarpo, reduzindo sua capacidade de regulaçăo das trocas hidricas, conforme o relatado por MOORE (1974) e SOAVE \& MORAES (1987).

Os dados relativos a porcentagem de germinaçăo apresentaram diferenças estatisticas entre os tratamentos de secagem, nas epocas $E_{1}, E_{3} e$ $E_{4}$, havendo alternancia de superioridade entre os tratamentos, de uma época para a outra. 
Tabela 20. Estudo 3 - Comparaçăo de médias dos dados de teor de água, germinaçăo, envelhecimento rápido e frio sem solo,nas épocas $E_{1}, E_{9}, E_{3}$, e $E_{4}$, para os efeitos de tratamentos de secagem.

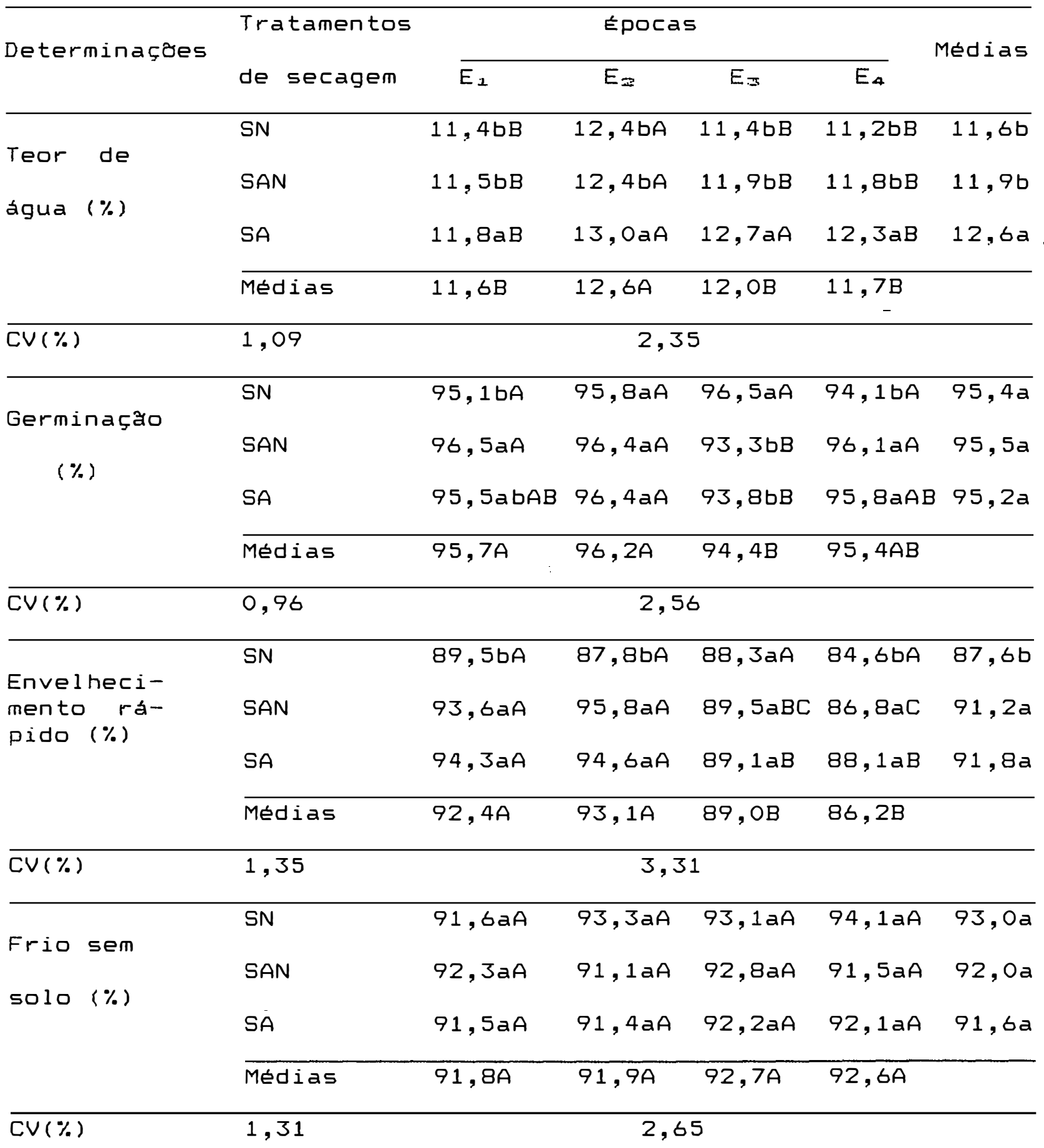

Médias seguidas pela mesma letra minúscula na mesma coluna e mesma letra maiúscula na mesma linha, năo diferem entre si pelo teste de Tukey, ao nivel de 5\% de probabilidade. 
Os resultados, obtidos no teste de envelhecimento rápido, denotam maior vigor das sementes dos tratamentos SAN e SA, em relaçăo as do tratamento SN, nas epocas $E_{\perp}, E_{\mp} e E_{4}$. Contudo, foram detectadas reduçäes consideráveis de vigor, nas sementes submetidas às secagens artificial-natural e artificial, após 120 dias de armazenamento.

o teste de frio sem solo, que tem se mostrado bastante sensivel para avaliar os efeitos da temperatura de secagem sobre a qualidade fisiológica de sementes de milho, conforme BURRIS \& NAVRATIL (1980), NAVRATIL (1980), NAVRATIL \& BURRIS (1984) e LOEFFLER et alii (1985), nå detectou efeitos dos tratamentos de secagem e do periodo de armazenamento sobre o vigor das sementes.

Os dados da Tabela 21, permitem constatar um declinio na porcentagem média de emergência das plantas em campo, de 94,6 para 86,3\% entre as épocas $E_{1}$ e $E_{4}$ e uma elevaça no nivel de infestaçăo por insetos, de 1,5 para $4,2 \%$

Cabe ressaltar que os insetos de armazenamento podem causar sérios danos às sementes, destacando-se as reduçães de peso e de qualidade fisiologica. Os danos no pericarpo da semente de milho provocam um aumento na velocidade respiratoria e uma consequente reduçå de vigor, enquanto, o ataque ao 
endosperma e ao embriao pode comprometer, inclusive a viabilidade (HOWE, 1975; POPINI!GIS, 1976; POPINIGIS, 1985 ; CARVALHO \& NAKAGAWA, 1988). A elevaçao do nivel de infestaçăo por insetos, durante o armazenamento, dentre outros fatores, pode ter contribuido para a reduçăo de vigor das sementes.

Tabela 21. Estudo 3. - Comparaçao de médias dos dados de emergência em campo e de sementes infestadas, nas epocas $E_{1}$ e $E_{4}$, para os efeitos de tratamentos de secagem.

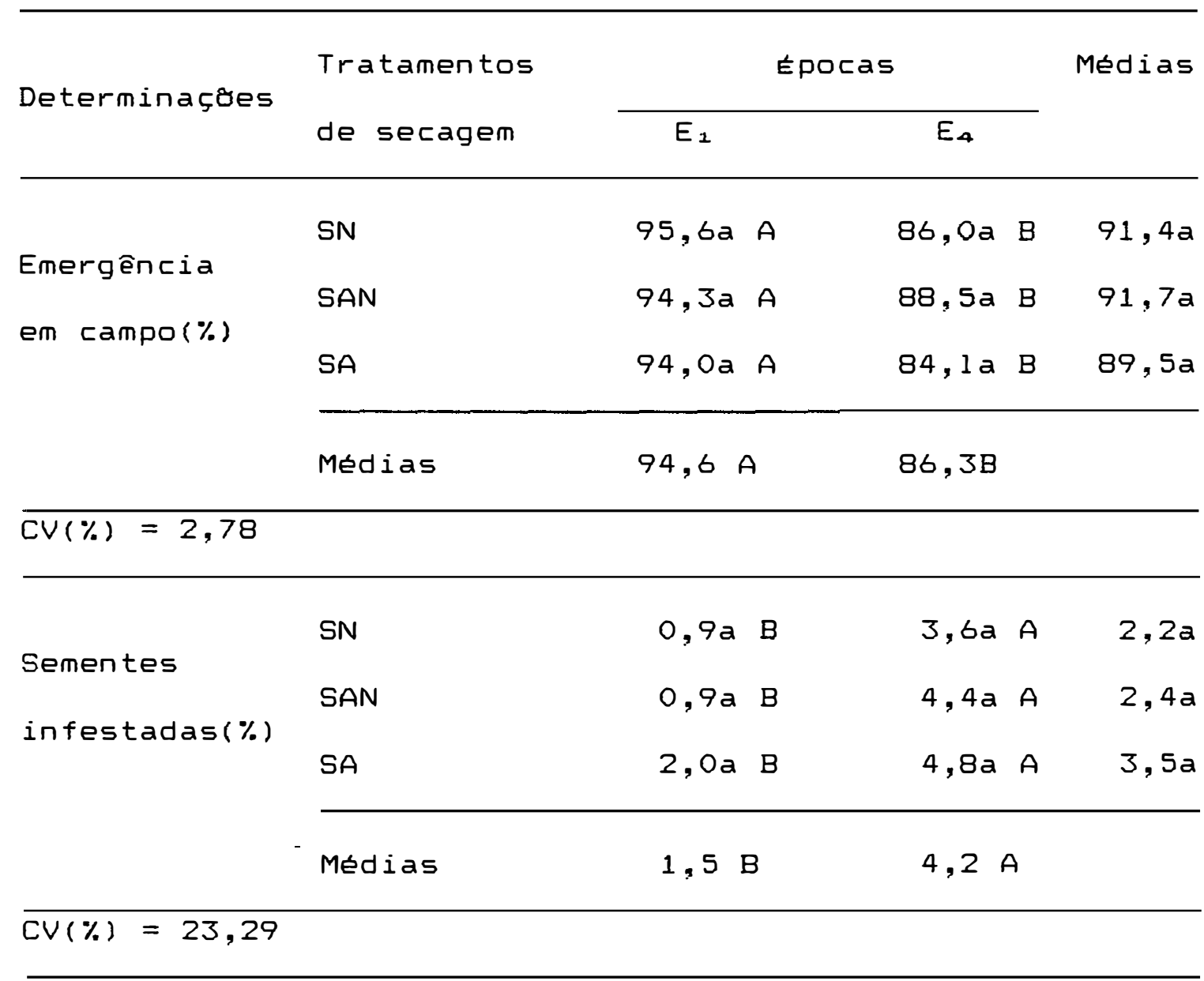

Médias seguidas pela mesma letra minúscula na mesma coluna e mesma letra maiúscula na mesma linha, nao diferem entre si pelo teste de Tukey, ao nivel de 5\% de probabilidade. 
As comparaçôs de médias de incidências de Penicillium spp., Aspergillus spp, Fusarium moniliforme e Cephalosporium spp., para os efeitos de tratamentos de secagem, nas épocas $E_{2}$ e $E_{4}$, săo apresentadas na Tabela 22. As sementes, submetidas ao tratamentos SAN e SA, apresentaram, na primeira época, resultados similares quanto à incidência de Penicillium spp. e significativamente inferiores ao tratamento SN. Durante o periodo de armazenamento, a incidência deste fungo, nas sementes submetidas ao tratamento SA, decresceu em $20,7 \%$, alcançando $60,2 \%$, na quarta época; este valor foi destacadamente inferior aos obtidos nas sementes submetidas aos tratamentos SN e SAN.

No tratamento SA, as sementes ficaram expostas ao ar aquecido a $90^{\circ} \mathrm{C}$, durante $82 \mathrm{~min}$ e atingiram a temperatura média de $390 \mathrm{C}$ (Tabela 7), o que poderia permitir o controle de patógenos, conforme o descrito por DHINGRA et alii (1980), SOAVE \& MORAES (1987) e MENTEN (1988), para sementes de algodao, tratadas com ar aquecido, a temperaturas de 90 a $1000 \mathrm{C}$, durante 12 h e para sementes de hortaliças, tratadas com vapor arejado, sob temperaturas de 52 a $56^{\circ} \mathrm{C}$, por 10 a $30 \mathrm{~min}$.

Os resultados, obtidos para a incidência de Penicillium spp., sugerem que a secagem artifical, à temperatura do ar de 90\% Controla o desenvolvimento deste patógeno associado às sementes. 
Tabela 22. Estudo 3-Comparação de médias de incidência de Penicillium spp., Aspergillus spp., Fusarium monilifarme e Cephalosporium spp., nas épocas $E_{1}$ e $E_{4}$, para os efeitos de tratamentos de secagem.

\begin{tabular}{|c|c|c|c|c|}
\hline \multirow{2}{*}{ Determinaçôes } & \multirow{2}{*}{$\begin{array}{l}\text { Tratamentos } \\
\text { de secagem }\end{array}$} & \multicolumn{2}{|c|}{ Épocas } & \multirow{2}{*}{ Médias } \\
\hline & & $\overline{E_{1}}$ & $\overline{E_{4}}$ & \\
\hline \multirow{2}{*}{ Penicillium } & SN & $97,8 a A$ & $95,0 a A$ & \\
\hline & SAN & $82,6 \sqcup A$ & $86,9 a A$ & 84,86 \\
\hline \multirow{2}{*}{ Spp. $(\%)$} & $S A$ & $80,9 \sqcup A$ & $60,2 b B$ & $71,1 b$ \\
\hline & Médias & $88,7 A$ & $82,8 A$ & \\
\hline \multicolumn{5}{|l|}{$\overline{C V}(\%)=8,39$} \\
\hline \multirow[t]{2}{*}{ Aspergillus } & SN & $5,6 a B$ & $15,2 a A$ & $10,0 a$ \\
\hline & SAN & $7,7 a B$ & $12,4 a A$ & \\
\hline \multirow{2}{*}{ spp. $(\%)$} & SA & $8,2 \mathrm{aB}$ & $13,0 a A$ & $10,5 a$ \\
\hline & Médias & $7,2 \mathrm{~B}$ & $13,5 A$ & \\
\hline \multicolumn{5}{|l|}{$\overline{C V}(\%)=17,78$} \\
\hline \multirow{4}{*}{$\begin{array}{l}\text { Fusarium } \\
\text { maniliforme } \\
(\%)\end{array}$} & SN & $8,8 a B$ & $43,6 a A$ & $26,3 a$ \\
\hline & SAN & $7,7 a B$ & $40,6 a A$ & $23,6 a$ \\
\hline & SA & $4,3 a B$ & $41,5 a A$ & $21,7 a$ \\
\hline & Médias & $6,8 \mathrm{~B}$ & $41,8 A$ & \\
\hline
\end{tabular}

$\mathrm{CV}(\%)=16,55$

\begin{tabular}{lllll}
\hline Cephalospo- & SN & $41,9 b A$ & $0,6 a B$ & $20,8 b$ \\
rium spp. (\%) & SAN & $51,4 a A$ & $0,4 a B$ & $26,4 a$ \\
& SA & $56,3 a A$ & $0,8 a B$ & $28,6 a$ \\
& Médias & $50,6 A$ & $0,5 B$ &
\end{tabular}

$\overline{C V}(\%)=16,44$

Médias seguidas pela mesma letra minúscula na mesma coluna e mesma letra maiúscula na mesma linha, nao diferem entre si pelo teste de Tukey, ao nível de $5 \%$ de probabilidade. 
Nå foram observadas diferenças significativas, entre os tratamentos de secagem, em cada época de avaliaçăo, com relaçăo a incidência de Aspergillus spp. e Fusarium moniliforme. Contudo, foi detectada uma maior incidência destes patógenos na época $E_{A}$, acompanhando a mesma tendência verificada para fusarium moniliforme nos Estudos 1 e 2 e para Aspergillus spp., no Estudo 2.

Na primeira época, quanto à incidência de Cephalosporium SpP., os tratamentos SA e SAN mostraram resultados análogos, além de superiores aos obtidos no tratamento SN. Entretanto, na quarta epoca, em que a ocorrência deste fungo foi efetivamente baixa, nå foram verificadas diferenças entre os tratamentos.

Fissuras internas em sementes podem nao afetar a germinaçăo imediatamente após sua ocorrência, entretanto, causam reduçôes no vigor e na longevidade, conforme o relatado por HARRINGTON (1972), MOORE (1974), JUSTICE \& BASS (1979) e SOAVE \& MORAES (1987). E oportuno destacar que este tipo de dano nao é, em principio, detectado no teste de coloraça em tintura de iodo e no exame de sementes com dano mecânico visivel, embora sua provável ocorrência, também possa ter contribuido para o declinio dos potenciais de conservaça durante o armazenamento e de emergência das plantas em campo.

De uma maneira geral, os resultados do Estudo 3, possibilitam constatar que embora as sementes, 
durante a secagem artificial (SA) á temperatura do ar de $90 \circ \mathrm{C}$, alcancem a temperatura máxima de $410 \mathrm{C}$, nå să observáveis efeitos negativos sobre a qualidade fisiologica. Quanto ao fungo Penicillium spp., à semelhança dos Estudos 1 e 2, denota-se uma menor incidência nas sementes submetidas à secagem artificial.

\section{4. Consideraçôes gerais}

Numa análise geral, pode ser verificado que os lotes utilizados nos três estudos apresentaram similitude em determinadas caracteristicas, como alta qualidade fisiológica inicial e decréscimos consideráveis desta qualidade ao longo do periodo de armazenamento; apesar disso, foram detectadas, algumas diferenças de qualidade, mos testes de envelhecimento rápido, de coloraçă de tintura de iodo e de sanidade, por ocasiao da caracterizaçă dos lotes.

Nos testes de germinaçă, frio sem solo, emergência em campo, coloraçao de tintura de iodo, nos exames de sementes infestadas e de sementes com danos mecănicos visiveis, na determinaçă do total de impurezas e nas incidências de Aspergillus spp., Fusarium manilifarme e Cephalosporium spp., nao foram observadas, de uma maneira geral, diferenças acentuadas entre os efeitos das secagens natural, artificial-natural e artificial, nos Estudos 1, 2 e 3. Por outro lado, foram constatadas diferenças entre os 
tratamentos de secagem, na determinaçao do teor de água, no teste de envelhecimento rápido e na incidencia de Penicillium SPP.

Com relaçăo as condiçoes ambientais de armazenamento, é possivel constatar que a temperatura e a umidade relativa do ar mantiveram-se em valores considerados satisfatórios a conservaçăo das sementes durante o armazenamento a curto prazo. o teor de água das sementes, por sua vez, nåo apresentou oscilaçôes apreciáveis, no decorrer do periodo experimental.

o declinio da qualidade das sementes, verificado no transcurso do periodo de armazenamento, possivelmente, foi motivado por fatores adversos, durante a maturaça fisiológica e na fase de pré-colheita e, muito provavelmente, pelos danos mecanicos por ocasiao da colheita. A incidência de sementes com danos mecânicos, avaliada pelo teste de coloraçă em tintura de iodo, variou de 15,1 a $22,0 \%$ (Tabelas 9,14 e 19), valores, estes, que podem ser considerados elevados, levando-se em conta que os danos internos nao sao, a priori, detectados neste teste.

Considerando que o nivel de energia remanescente numa semente, para a execuça do processo germinativo após determinado periodo de armazenamento, é inferior ao do momento da ocorrência do dano (MOORE, 1974 e CARVALHO \& NAKAGAWA, 1988) é provável que os danos mecânicos tenham concorrido para minorar o potencial de 
conservaçăo e o desempenho no campo.

$\mathrm{Na}$ conduçåo de novos estudos, similares aos

realizados neste trabalho, sugere-se a utilizaça do teste de tetrazólio, para determinar a localizaço e a extensao dos danos embrionários, com a finalidade de interpretar as causas do desempenho das sementes em outros testes.

Por outro lado, vale destacar que as áreas afetadas, segundo MOORE (1974), servem como centros de desenvolvimento para os fungos de armazenamento, de tal forma que a extensåo e a localizaça dos danos exercem considerável influência na suscetibilidade da semente à deterioraçao por patógenos.

A presença de fungos de armazenamento, principalmente Penicillium spp, cuja porcentagem de ocorrência foi elevada nos três lotes, embora nåo tentha afetado a viabilidade das sementes, pode ter influido no vigor e no desempenho das plāntulas em campo, apesar da secagem artificial ter, de certa forma, controlado o desenvolvimento deste patógeno.

E importante ressaltar, ainda, que as sementes utilizadas no presente trabalno nao foram tratadas com fungicidas, o que poderia contribuir, conforme DHINGRA et alii (1980), LASCA (1986), SOAVE \& MORAES (1987) e MENTEN (1988), no sentido de controlar os patógenos associados as sementes, proteger as sementes contra fungos de armazenamento, resguardar as sementes e as plântulas de 
microrganismos de solo e propiciar uma proteçao residual à planta contra patógenos da parte aérea nas fases iniciais de desenvolvimento da cultura.

A secagem pode contribuir para a reduça da qualidade fisiológica das sementes no armazenamento; contudo, esta operaçăo năo deve ter contribuido, de forma considerável, para acelerar o processo de deterioraçao, visto que, a massa de sementes atingiu temperaturas máximas de $350 \mathrm{C}, 390 \mathrm{C}$ e 410C, ao utilizar-se, no secador intermitente, respectivamente, ar aquecido a $700 \mathrm{C}, 800 \mathrm{C} \mathrm{e}$ $90^{\circ} \mathrm{C}$. Esta constataçao está em consonância com os resultados alcançados por ROSA (1966) e LUZ (1986), na secagem de sementes de arroz pelo metodo intermitente, utilizando temperaturas do ar de $70^{\circ} \mathrm{C}$, onde verificaram que a massa de sementes atingiu a temperatura máxima de $42,2^{\circ} \mathrm{C}$, sem causar efeitos imediatos ou latentes sobre a qualidade fisiológica. Por sua vez, MIRANDA (1978), ao proceder a secagem de sementes de soja, em secador intermitente, a temperatura do ar de 45 , 60 e $750 \mathrm{C}$, concluiu que a temperatura da massa de sementes, visando minimizar a velocidade de deterioraça, nao deve ultrapassar a 36,70C. - Na secagem intermitente, en razao do arrefecimento existente durante o periodo de repouso, podem ser utilizadas altas temperaturas do ar, sem que a temperatura das sementes atinja niveis prejudiciais a sua qualidade fisiológica. Referindo-se a este aspecto, RasA 
(1966) afirma que a temperatura da massa de sementes conserva-se abaixo da temperatura do ar de secagem, devido ao resfriamento que elas sofrem, quando nåo estao sob a açăo do ar aquecido e a maior evaporaçăo de água, por unidade de tempo efetivo de secagem. Em decorrência deste último fato, as sementes perdem calor com maior intensidade, mantendo-se a temperaturas mais baixas.

A baixa condutividade térmica e o alto calor especifico das sementes de milho sao fatores que, provavelmente, também exerçam influência sobre este comportamento durante a secagem, levando em conta os relatos de KEEY (1975), LASSERAN (1978) e FORTES \& OKOS $(1980)$.

Uma técnica bastante promissora para a secagem de sementes de milho, em regiöes ou periodos de clima seco, é a secagem em combinaço. Após a colheita das. sementes, com teor de água ao redor de $20 \%$, procede-se a secagem intermitente em altas temperaturas até teores de água de 15 a $16 \%$, complementando-se, a seguir, o processo num sistema em baixa temperatura. Desta forma haverá, provavelmente, um aumento na capacidade operacional dos equipamentos, sem efeitos prejudiciais a qualidade das sementes. Esta alternativa, entretanto, carece de maiores informaçąes, havendo necessidade de novos estudos.

Levando em consideraça os resultados alcançados, no presente trabalho, sugere-se a continuidade 
deste tipo de pesquisa, contemplando aspectos que envolvam sementes com teores de água em torno de $20 \%$, por ocasiăo da colheita; temperaturas do ar de secagem superiores a 900C; considerando o binômio temperatura da massa de sementes e o tempo de exposiça das sementes ao ar aquecido; outros testes para avaliaça da qualidade das sementes, tais como, - de tetrazólio e o de condutividade eletrica, com o objetivo de fornecer mais subsidios para a melhor utilizaçăo do método intermitente, na secagem de sementes de milho. 


\section{CONCLUSÕES}

A reuniao das informaçoes fornecidas pelo presente trabalio, considerando temperaturas do ar de secagem de 70,80 e $90^{\circ} \mathrm{C}$ e reduçâs do teor déágua de 16,5 para 13,0\%, permite as seguintes conclusoes:

- A secagem intermitente năo causa efeitos prejudiciais à qualidade fisiologica de sementes de milho. - A incidencia de Penicillium spp. em sementes de milho pode ser reduzida pelo emprego da secagem intermitente.

- As curvas de secagem de sementes de milio, na secagem intermitente podem ser representadas por funçoses lineares.

- o aumento da velocidade de secagem e a reduçăo do tempo total de exposiçăo das sementes ao ar aquecido podem ser obtidos pela elevaça da temperatura do ar de secagem. 


\section{REFERENCIAS BIBL IOGRÁF ICAS}

ALVARENGA, L.C. Transporte de água em graos de feijåo preto sob condiçøes de secagem e repouso. Viçosa, 1979 , 58 p. (Mestrado - Universidade Federal de Viçosa).

ASSOCIATION OF OFFICIAL SEED ANALYSTS. Seed vigor testing handbook. Zurich, 1983. 88p (Handbook on Seed Testing. Contrib., 32).

BASKIN, C.C. Seed storage-biological aspects. In: SHORT COURSE FOR SEEDSMEN, Mississippi State, 1975. Proceedings. Mississippi, Mississippi State University, 1975. P. 77-80.

BDLIYA, P.M. \& BURRIS, J.S. Dialled analysis of tolerance of drying injury in seed corn. Crop Science, Madison, $28(6): 935-8,1988$.

BItRAN, E.A. Controle quimico de pragas dos graos armazenados. IN: SEMINÁRIOS SOBRE CONTROLE DE INSETOS, Campinas, 1987. Anais. Campinas, Fundaçăo Cargill, 1989. P. 2-15. 
BOYD, A.H. Heated air drying of soybean (Glycine max (L.) Merrill) seed. Mississippi, 1974. 90 p. (Ph.D.Mississippi State University).

Bounous, E.B. Comparaçăo de métodos de secagem em sementes de azevém anual (Lolium multiflorum L.). Pelotas, 1986. 109 P. (Mestrado-Universidade Federal de Pelotas).

BRASIL, Ministério da Agricultura. Secretaria Nacional de Defesa Agropecuaria. Regras para analise de semente. Brasilia, 1980. 188 p.

BROOKER, D.B.; BAKKER-ARKEMA, F.W.; HALL, C.W. DrYing cereal grains. Westport, AVI Publishing, $1974.265 \mathrm{p}$.

BURRIS, J.S. \& NAVRATIL, R.J. Drying high - moisture seed corn. In: 3STH ANNUAL CORN \& SORGHUM RESEARCH CONFERENCE, Iowa State, 1980. Proceedings. Ames, Iowa State University, 1980. P. $116-32$.

CABELLO, S.D. Importancia, procedimientos y aspectos practicos en el secado de semillas. In: ACTUALIzACION sobre tecnologia de Semillas, México, 1982. Memariais. México, Universidad Autonoma Agraria Antonio Narro, 1982. P. $37-46$. 
CARVAlHo, N.M. \& Nakagawa, J. Sementes; ciência, tecmologia e produçăo. 3.ed. Campinas, Fundaçăo Cargill, 1988. $424 p$.

CAVARIANI, C. Efeitos da secagem intermitente sobre a qualidade da semente de soja (Glycine max (L.) Merrill). Pelotas, 1983. 128p. (Mestrado-Universidade Federal de Pelotas).

CAVARIANI, C. \& BAUDET, L.M.L. Secagem de sementes. Informe Agropecuario, Belo Horizonte, 8(91): 44-9, 1982.

COATES, E.S. Grain and seed drying fundamentals. In: SHORT COURSE FOR SEEDSMEN, Mississippi State, 1960. Proceedings. Mississipi, Mississippi State University, 1960. P.111-8.

COPELAND, L.O. \& MCDONALD, M.B. Principles of seed science and technolagy. Minneapolis, Burgess. 1985. $321 \mathrm{p}$.

CORREA, C.F. Secagem de sementes de arroz l.oryza sativa L.) em silo secador com distribuiça radial de ar. Pelotas, 1981. 85p. (Mestrado - Universidade Federal de Pelotas).

CROSS, H.Z. A selection procedure for ear drying-rates in 
maize. Euphytica, Dordrecht. 34: 409-18, 1985.

DalPasquale, V.A.; Queiroz, D.M.; PERE IRA, J.A.M.; Sinicio, R. Secagem de graos em altas temperaturas. Vicosa, CENTREINAR, $1987.47 P$.

DANIELL, J.W.; CHAPPELL, W.E.; COUCH, H.B. Effect of sublethal and lethal temperatures on plant cells. Plant Physialogy, Rochville, 44: 1684-9, 1969.

DELOUCHE, J.C. \& POTTS, H.C. Programa de sementes; planejamento e implantaçao. Brasilia, AGIPLAN, 1974. $124 P$.

DELOUCHE, J.C.; MATTHES, R.K.; DOUGHERTY, G.M.; BOYD, A.H. Storage of seed in sub-tropical and tropical regions. Seed Science and Technolagy, Zurich, 1: 671-700, 1973.

DHINGRA, O.D.; MUCHOVEJ, J.J.; CRUZ FILHO, J. Tratamento de sementes (controle de patogenos). Vicosa, UFV, 1980. $121 P$

FORTES, M. A non-equilibrium thermodynamics approach to transport phenomena in capillary-porous media with special reference to drying of grains and foods. West Lafayette, 1978. 172p. (Ph.D. - Purdue University). 
FORTES, M. \& OKOS, M.R. Changes in physical properties of corn during drying. Transactions of the ASAE, st. Joseph, 23(4): 1004-8, 1980 .

FOUST, A.S.; WENZEL, L.A.: CLUMP, C.W.; MAUS, L.; ANDERSEN, L.B. Principias das operaģes unitarias. Rio de Janeiro, Guanabara Dois, 1982. 670p.

GUILBOT, A.; MULTON, Y.L.; MARTIN, G. Determination de la teneur en eau des semences. Seed Science and Technology, Zurich, 1(3): 587-611, 1973.

GUNASEKARAN, S. \& PAULSEN, M.R. Breakage resistance of corn as function of drying rates. Transactions of the ASAE, St. Joseph, 28(6): 2071-6, 1985.

GUSTAFSON, R.J. \& MOREY, R.V. Study of factors affecting quality changes during high-temperature drying. Transactions of the ASAE, St. Joseph, 22(4): 926-32, 1979.

GUSTAFSON, R.J. \& MOREY, R.V. Moisture and quality variations across the column of a crossflow grain dryer. Transactions of the ASAE, St. Joseph, 24(2): 1621-5, 1981. 
GUSTAFSON, R.J.; MOREY, R.V.; CHRISTENSEN, C.M.; MERONUCK, R.A. Quality changes during high-low temperature drying. Transactions of the ASAE, St. Joseph, 21(1): $161-9,1978$.

HALL, C.W. Drying and storage of agricultural crops. Westport, Avi Publishing, 1980. 382p.

HARRINGTON, J.F. Seed storage and longevity. In: KOZLOWSKI, T.T. Seed bialogy. New York, Academic Press, 1972. v. 3, p.145-245.

HARRINGTON, J.F. Packaging seed for storage and shipment. Seed Science and Technology, Zurich, 1(3): 701-9, 1973.

HENDERSON, S.M. \& PERRY, R.L. Agricultural process engineering. New York, John Wiley \& Sons, 1955. 604p.

HERTER, U. Effect of drying on corn seed quality. Ames, 1987. 173p. (Ph.D - Iowa State University).

HERTER, U. \& BURRIS, J.S. Effect of drying rate and temperature on drying injury of corn seed. Canadian Journal of Plant Science, Ottawa, 69(3): 763-74, 1989a.

HERTER, U. \& BURRIS, J.S. Evaluating drying injury on corn 
seed with a conductivity test. Seed Science and Technology, Zurich, 17: 625-38, 1989b.

HOWE, R.W. Loss of viability of seed in storage attributable to infestations of insets and mites. Seed Science and Technology, Zurich, 1: 563-86, 1973.

HUKILL, w.V. Grain drying. In: CHRISTENSEN, C.M. Storage of cereal grains and their products. Minnesota, American Association of Cereal Chemists, 1972. v.2, P. 481-508.

JUSTICE, O.L \& B BSS. L.N. Principles and practices of seed storage. London, Castle House, 1979. 289p.

KEEY, R.B. Drying: principles and practice. 2a.ed. Oxford, Pergamon Press, 1975.340 .

KEEY, R.B. Introduction to industrial drying operations. Oxford, Pergamon Press, 1978. 371p.

KNEULE, F. El secado. Bilbao, Urmo, 1966. 405p.

KREYGER, J. Practical observations on the drying of seed. Seed Science and Technology, Zurich, 1: 645-70, 1973. 
LASCA, C.C. Tratamento de sementes. In: SIMPOSIO BRASILEIRO de patologia de sementes,. 2., Campinas, 1986. Anais. Campinas, $1986.0 .93-9$.

LASSERAN, J.C. Principios gerais de secagem. Revista Brasileira de Armazenamento, Viçosa, 3(3): 17-45, 1978.

LASSERAN, J.C. Caracteristicas técnicas dos secadores. Revista Brasileira de Armazenamento, Viçosa, 4(2): 4-14, 1979.

LASSERAN, J.C. Utilizaçao e desempenho de secadores: possibilidades de aperfeiçoamento. Revista Brasileira de Armazenamento, Viçosa, 5(1): 50-60, 1980.

LEE, J.F \& SEARS, F.W. Termodinåmica. Rio de Janeiro, Livro Técnico, 1969. 667p.

LOEFFLER, N.L.; MEIER, J.L.; BURRIS, J.S. Comparison of two cold test procedures for use in maize drying studies. Seed Science and Technology, Zurich, 13: $653-8,1985$.

LuCCA FILHO, O.A. Testes de sanidade de sementes de milho. In: SOAVE, J. \& WETZEL, M.M.V.S. Patologia de sementes. Campinas, Fundaço Cargill, 1987, P. 430-40. 
LUz, C.A.S. da. Secagem de sementes de arroz em secador intermitente lento. Pelọtas, 1986. 103p. (Mestrado Universidade Federal de Pelotas).

McLEAN, K.A. Drying and storing combinable crops. Ipswich, Farming, 1980. 280p.

MARCOS FILHO, J.; CICERO, S.M.; SILVA, W.R. Avaliaçă da qualidade das sementes. Piracicaba, FEALQ, $1987.230 p$.

MATTHES, R.K.; WELCH, G.B.; DELOUCHE, J.C.; DOUGHERTY, G.M. Drying, processing and storage of corn seed in tropical and subtropical regions: Michigan, ASAE, 1969. 28p. (ASAE Paper, 69-577).

MEIER, J.L. A survey of genotipe susceptibility to drying injury in maize seeds. IOWA Seed Science, Ames, 5(1): $4-5,1983$.

MENEZES, M. Aspectos diagnósticos na deteç̧o de Fusarium em sementes. In: SIMPOSIO BRASILEIRO DE SEMENTES, 3., Campinas, 1988. Anais. Campinas, 1988. p.140-56.

MENTEN, J.0.M. Importância da semente na transmissao de patógenos. In: SIMPOSIO BRASILEIRO DE PATOLOGIA DE SEMENTES, 2.Campinas, 1986. Anais. Campinas,1986. p.27-40. 
MENTEN, J.O.M. I Semana de atualizaçăo em patologia de sementes. Piracicaba, FEALQ, 1988. 76p.

MIRANDA, T.R. Secagem intermitente lenta de sementes de soja (Glycine max (L.) Merrill). Pelotas, 1978. 93p. (Mestrado - Universidade Federal de Pelotas).

MOES, J. \& VYN, T.J. Management effects on kernel breakage susceptibility of early maturing corn hybrids. Agronomy Journal, Madison, 80: 699-704, 1988.

MOORE, R.P. Effects of mechanical injuries on viability. In: ROBERTS, E.H. Viability of seeds. London, Chapman and Hall, 1974. P.94-113.

NAVRATIL, B. Effects of high temperature drying on corn seed quality. Iowa Seed Science, Ames, 2(1): 1-2, 1980.

NAVRATIL, R.J. \& BURRIS, J.S. The effect of drying temperature on corn seed quality. Canadian Journal of Plant Science, Ottawa, 64: 487-96, 1984.

NELLIST, M.E. Safe drying temperatures for seed grain. In: HEBBLETH-WAITE, P.D., Seed Production. London, Butterworths, $1980 . \quad$ P.371-88. 
NELLIST, M.E. \& HUGUES, M. Physical and biological processes in the drying of seed. Seed Science and Technology, Zurich, 1(3): 613-43, 1973.

PARK, K.J. Fundamentos de secagem. In: CURSO. DE APERFEiçOAMENTO EM tecnologia de Alimentos, Campinas, 1988. Apostila. Campinas, UNICAMP, 1988. $26 \mathrm{p}$.

PARRISH, D.C. \& LEOPOLD, A.C. On the mechanism of ageing of soybean seeds. Plant Physiology, Rockville, 61: $365-8,1978$.

PESKE, S.T. \& AGUIRRE, R. Manual para operadores de unidades de beneficio de semillas (UBS). Cali, Colombia, CIAT, 1987. 117P.

PESKE, S.T. \& BAUDET, L.M.L. Consideracôes sobre secagèm, de sementes, Viçosa, CENTREINAR, 1980. 19p.

POPINIGIs, F. Qualidade fisiologica de sementes. Semente, Brasilia, 1(1): 65-80, 1975 .

POPINIGIS, F. Preservaça da qualidade fisiológica da semente durante o armazenamento. Brasilia, EMBRAPA, 1976. 63p. 
POPINIGIS, F. Fisiologia da semente. Brasilia, s.ed., 1985. 289p.

PURDY, J.L. \& CRANE, P.L. Inheritance of drying rate in mature corn (Zea mays L.). Crop Science, Madison, 7: 294-7, 1967.

PUZZI, D. Abastecimento e armazenamento de grăos. Campinas, Instituto Campineiro de Ensino Agricola, 1986. $603 p$.

ROBERTS, E.H. Physiology of ageing and its application to drying and storage. Seed Science and Technology, Zurich, 9: 359-72, 1981 .

ROCKLAND, L.B. Water activity and storage stability. Food Technology, Chigago, 23: 1241-51, 1969.

ROSA, 0.S. Temperaturas recomendadas para a secagem de sementes de trigo e arroz utilizando o metodo intermitente. In: SEMINÁRIo PANAMERICANO DE SEMILLAS, 5., Macaray, 1966. Anais. Macaray, 1966. 27p.

SEYEDIN, N.; BURRIS, J.S.; FLYNN, T.E. Physiological studies on the effects of drying temperatures on corn seed quality. Canadian Journal of Plant Science, 
Ottawa, 64: 497-504, 1984 .

SILVA,J.S.; LACERDA FILHO, A.F.; DALPASQUALE, V.A. Métodos de secagem e secadores. Informe Agropecuario, Belo Horizonte, $9(99): 3-5,1983$.

SIlVA, W.R. Secagem das sementes. In: CICERO, S.M.; MARCOS FILHO, J.; SILVA, W.R., org. Atualizaçăo em produçă de sementes. Campinas, Fundaçao Cargill, 1986. P. 155-82.

SILVEIRA, G.M. Tipos de secadores e métodos de operaçôes. A granja. Porto Alegre, 340: 28-33, 1976.

SOAVE, J. \& MORAES, S.A. Medidas de controle das doenças transmitidas por sementes. In: SOAVE, J. \& WETZEL, M.M.V.S. Patologia de sementes. Campinas, Fundaçao Cargill, 1987. P.192-259.

SODHA, M.S.: BANSAL, N.K.; KUMAR, A., BANSAL, P.K. MALIK, M.A.S. Solar crop drying. Volume I. Boca Raton, CRC Press, $1987.141 \mathrm{P}$.

TOLEDO, F.F. de \& MARCOS FILHO, F. Manual das sementes; tecnologia da produçăo. Såo Paulo, Agronomica Ceres, 1977. 224p. 
TOTH, A. \& SULLER, Á. Examination of maize; seed drying process. International Agrophysics, Budapest, 3(4): $343-52,1987$.

VEGA, C.R. Efeito do método de secagem sobre a qualidade da semente de arroz (Oryza sativa L.). Pelotas, 1989, 123p. (Mestrado - Universidade Federal de Pelotas).

VILLA, G.L. \& ROA, G. Secagem e armazenamento de soja industrial e sementes a granel. Campinas, Fundaçă Cargill, 1979. 64p.

WELCH, G.B. Articles on seed drying. Seedsmen's Digest. Mississippi, Mississippi State University, 1967. 15p.

WETZEL, M.M.V.S.Fungos de armazenamento. In: SOAVE, J.\& WETZEL, M.M.V.S. Patologia de sementes.Campinas,Fundaçăo Cargil1,1987. P.260-75.

ZONTA, E.P.; MACHADO, A.D.; SILVEIRA JUNIOR, P. Sistema de Analise Estatistica para Microcomputadores - SANEST. Pelotas, 1984 . 